\title{
HARVEST INDEX OF PEA PLANT AND SOIL PROPERTIES INFLUENCED BY A TWO-YEAR AMENDMENT OF BIOCARBONS UNDER MUNICIPAL WASTEWATER IRRIGATION IN ARID CLIMATE
}

\author{
MANZOOR, M. $.^{1,2^{*}}-$ GUL, S. ${ }^{1,3}-$ BIBI, S. ${ }^{4}-$ GUL, I. ${ }^{3,5}-$ AKBAR, A. ${ }^{6}-$ ALI, I. ${ }^{7,8}-$ ReHMAN, G. B. ${ }^{1}$ \\ ${ }^{I}$ Department of Botany, University of Balochistan, Quetta, Balochistan, Pakistan \\ ${ }^{2}$ Department of Plant Sciences, Sardar Bhadur Khan Women's University, Quetta, Balochistan, \\ Pakistan \\ ${ }^{3}$ Department of Natural Resource Sciences, Macdonald Campus, McGill University, 21111 \\ Lakeshore Road, Ste-Anne-de-Bellevue, H9X 3V9 Quebec, Canada \\ ${ }^{4}$ Institute for Ecology, Technical University, Berlin, Germany \\ ${ }^{5}$ Institute of Environmental Sciences and Engineering, School of Civil and Environmental \\ Engineering, National University of Sciences and Technology (NUST), Islamabad, Pakistan \\ ${ }^{6}$ Department of Microbiology, University of Balochistan, Balochistan, Pakistan \\ ${ }^{7}$ Department of Biochemistry, University of Balochistan, Quetta, Pakistan \\ ${ }^{8}$ School of Life Sciences and Engineering, Southwest University of Science and Technology, \\ 621010 Mianyang, China \\ *Corresponding author \\ e-mail:Alfa_botany@yahoo.com \\ (Received $8^{\text {th }}$ Sep 2020; accepted $27^{\text {th }}$ Jan 2021)
}

\begin{abstract}
In this study, the influence of biochars, produced from cow manure and wood, on the harvest index of pea plants (Pisum sativum L.) and soil properties under groundwater and municipal wastewater irrigation was investigated. Biochars were applied at 5,10 and $15 \mathrm{tha}^{-1}$ rates for two years. Yield biomass (pods) was higher under groundwater irrigation. As compared to control, amendment of biochar did not influence harvest index for both years, under irrigation treatments; however, as compared to wastewater irrigation, harvest index tended to be higher under groundwater irrigation. Soluble phosphorus level was higher in response to manure derived biochar under groundwater irrigation and nitrogen level was higher in response to lower rate of manure derived biochar under wastewater irrigation as compared to groundwater-irrigated soil. Under wastewater, macroaggregate stability was significantly increased within the soil as compared to groundwater irrigation, while; macroaggregates stability was observed in response of wood-derived biochar at higher rate under groundwater irrigation. Bacterial diversity was two-fold higher in the soil irrigated with groundwater as compared to the soil irrigated with wastewater.
\end{abstract}

Keywords: bacterial diversity, soil aggregation, biochar, pea plants, biomass

\section{Introduction}

Baluchistan has arid to semi-arid climate and diversified precipitation. It consists of an area larger than other provinces of Pakistan, this has significant importance for agricultural activities (Ahmad and Islam, 2011). Inadequacy of water and poor quality of soil is the main hurdle for crop productivity in this province. However, urban areas 
have more practice of wastewater than groundwater irrigation and short-term studies demonstrate its significant positive influence on crop growth (Haider et al., 2018; Hameeda et al., 2019). Generally; overpopulation, economic development and urbanization have increased the wastewater effluent production from industries, commercial and domestic sources. This effluent is continuously contaminating the groundwater resources, environment and polluting the soil (Elgallal et al., 2016; Libutti et al., 2018). Irrigation of agricultural lands with wastewater can be a mean of its utilization as a bioresource and can be an effective way to reduce its effect on the environment. However, as wastewater can contain toxic chemicals (e.g., heavy metals) and excess amount of nutrients, continuous irrigation can have a negative influence on crop growth and soil quality (Murtaza et al., 2010).

The amendment of biocarbon, which is also known as biochar is found to have a positive influence on crop growth and soil quality under wastewater irrigation and crop (Kamran et al., 2019; Nzedigwu et al., 2019). For this, wastewater with biochar amendments can be the best substitute of groundwater for agricultural purposes and to improve crop yield and soil quality (Akoto-Danso et al., 2018; Haider et al., 2019). Concurrently, biochars amendment are in common practice in Pakistan to overcome nutrients deficiency in soil of arid climatic region; however, influence of biochar types, biochar production is associated with soil physiochemical properties, and climatic region of that area (Jeffery et al., 2011; Gul et al., 2015; Yadav et al., 2017) (metaanalysis). Besides, wood derived biochar, animal manure is the best option to produce biochar for being cost effective and frequently available and it is the rich source of nutrients. Interestingly, manure and wood derived biochars are reported for increase in yield and improvement of soil quality (Hameeda et al., 2019).

Pea plant has high agronomic importance and it is a common vegetable in Pakistan. Pea seeds (pods) consumed as a food and stover is used as a forage; however, after harvesting the above ground crop, under-ground part increases the nutrients availability in soil. Pea plant is the rich source of dietary fiber, micronutrients and protein; this is a healthy and economically affordable source of food for poor population. For this, pea plant is being extensively cultivated in Pakistan and in all over the world (Manzoor et al., 2019). In Pakistan pea is being cultivated in an area of 26569 ha and has $1465411 \mathrm{t}$ production. Punjab has the highest production, followed by KPK, Balochistan and Sindh. Sindh has the lowest production of pea (Fruit, Vegetables and Condiments Statistics of Pakistan 2017-2018).

In the arid climate of Quetta, Balochistan pea production was about $12369 \mathrm{t}$ from 2015 to 2018. Above mentioned statistics showed that climate of Quetta, Baluchistan is suitable for the cultivation of pea crop but there is need to bring changes in agricultural practices. Higher nutrients availability in soil can bring a significant increase in yield under wastewater irrigation. Generally, biochar amendments can improve the soil quality by increasing soil $\mathrm{pH}, \mathrm{EC}$, organic matter and soil microbial diversity and in results, increase the soil aggregates stability under wastewater irrigation. Higher crop production of pea plant under wastewater irrigation is linked to an increase in soil fertility. Uncertainties remained regarding interaction between biochar and wastewater irrigation.

For this, present study evaluated the influence of two types of biochar (manure and wood) on harvest yield index, soil properties $(\mathrm{pH}, \mathrm{EC}$, organic matter, $\mathrm{C}: \mathrm{N}$ ratio, mineral nitrogen, soluble phosphorus and aggregates stability), and bacterial diversity under groundwater and wastewater irrigation treatments for two years. Our hypothesis 
is (1) wastewater irrigation positively influence harvest index of pea plant and improves soil quality (2) amendment of biochar further improves harvest index of pea soil quality under wastewater irrigation.

\section{Materials and methods}

\section{Biochar and manure source and preparation}

Wood biochar was purchased from the local timber market and cow manure was collected from a dairy farm. Both biochar types were processed to slow pyrolysis by using local kiln and temperatures was about 350-500 ${ }^{\circ} \mathrm{C}$ (Manzoor et al., 2019). Wood derived biochar was crushed, passed through $2 \mathrm{~mm}$ and $0.65 \mathrm{~mm}$ sieves to obtain two particle-sizes of $2 \mathrm{~mm}$ and $0.65 \mathrm{~mm}$ and only $2 \mathrm{~mm}$ particle-sized was selected for manure derived biochar; however, fresh manure was evenly added to the plots. Properties of biochar (wood and manure) and irrigation treatments (groundwater and wastewater) are described as follows (Table 1).

Table 1. Biochars (wood and cow manure) and wastewater properties are listed

\begin{tabular}{c|c|c|c|c|c}
\hline Factors & pH & EC & Organic matter $(\%)$ & Nitrogen $\left(\mathbf{g ~ k g}^{-1}\right)$ & Phosphorus $\left(\mathbf{g ~ k g}^{-1}\right)$ \\
\hline Wood biochar & 7 & 5 & 71 & 10 & 11 \\
Cow manure biochar & 8 & 3 & 35 & 11 & 14 \\
Wastewater & 3 & 1720 & - & - & - \\
\hline
\end{tabular}

In May soil sampling was done at $10 \mathrm{~cm}$ depth from each plot, soil was sealed in the bags and was air dried at room temperature in the lab.

\section{Field area and experimental design}

Field trial was established in the Botanical Garden of University of Baluchistan, Quetta, Pakistan. 60 plots $\left(2 \times 2 \mathrm{~m}^{2}\right)$ were plotted in the open field; 30 plots were irrigated with groundwater and 30 were irrigated with wastewater irrigation. Biochar (wood and cow manure) types, application rates and irrigations treatments were analyzed by three factorial experimental design. Plots of both irrigation treatments were plotted separately. The experiment was established for the years of 2016-2017 in the early spring. Ten different treatments of biochars were applied for each irrigation treatment (Table 2). Each treatment was followed by three replicates under groundwater and wastewater irrigation (Fig. 1). Cow dung was evenly mixed in the sixty plots at the rate of $5 \mathrm{t} \mathrm{h}^{-1}$. Plots were irrigated twice before the cultivation of pea plant in the first week of October. Finally, in January about 100 seeds were sown in each plot and were regularly irrigated until harvested. In April, plants were on flowering stage and harvested in the first week of May.

\section{Harvest index}

After harvesting the crop, plants were air dried and on the basis of plant dry weight, aboveground biomass and harvest index (Unkovich et al., 2010) was estimated by Equation 1: 
Table 2. Treatments, their application rates and abbreviations

\begin{tabular}{c|c|c|c}
\hline Biochar types & Particles size & Application rate & Abbreviations \\
\hline Control & -- & $0 \mathrm{~kg} \mathrm{~m}^{-2}$ & $\mathrm{GW} / \mathrm{WW}$ \\
\hline \multirow{5}{*}{ Wood biochar } & $2 \mathrm{~mm}$ & $0.5 \mathrm{~kg} \mathrm{~m}^{-2}$ & $\mathrm{BW} .5$ \\
& $2 \mathrm{~mm}$ & $1 \mathrm{~kg} \mathrm{~m}^{-2}$ & $\mathrm{BW} 1$ \\
& $2 \mathrm{~mm}$ & $1.5 \mathrm{~kg} \mathrm{~m}^{-2}$ & $\mathrm{BW} 1.5$ \\
& $0.65 \mathrm{~mm}$ & $0.5 \mathrm{~kg} \mathrm{~m}^{-2}$ & $\mathrm{BW}(.65) .5$ \\
& $0.65 \mathrm{~mm}$ & $1 \mathrm{~kg} \mathrm{~m}^{-2}$ & $\mathrm{BW}(.65) 1$ \\
& $0.65 \mathrm{~mm}$ & $1.5 \mathrm{~kg} \mathrm{~m}^{-2}$ & $\mathrm{BW}(.65) 15$ \\
\hline \multirow{3}{*}{ Manure biochar } & $2 \mathrm{~mm}$ & $0.5 \mathrm{~kg} \mathrm{~m}^{-2}$ & $\mathrm{BM} .5$ \\
& $2 \mathrm{~mm}$ & $1 \mathrm{~kg} \mathrm{~m}^{-2}$ & $\mathrm{BM} 1$ \\
& $2 \mathrm{~mm}$ & $1.5 \mathrm{~kg} \mathrm{~m}^{-2}$ & $\mathrm{BM} 1.5$ \\
\hline
\end{tabular}

Field

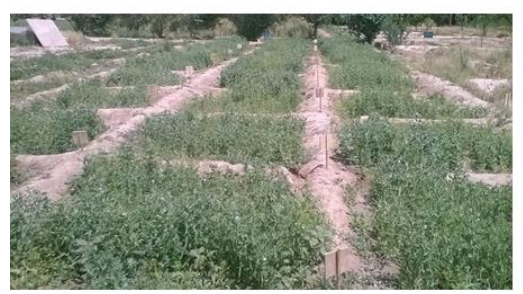

Plot

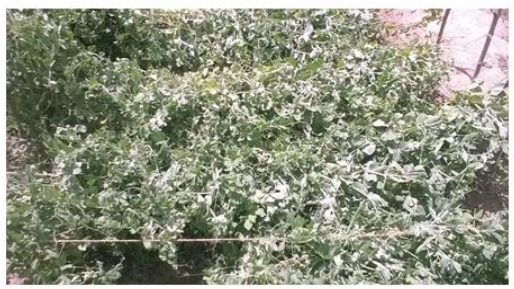

pods

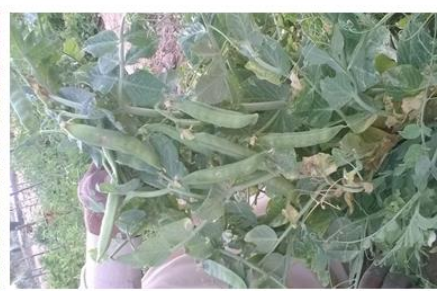

Figure 1. Growth of pea plant in the field, plot and pods under arid climate

\section{$P h, E C$ and organic matter in soil}

Crop was harvested in May and soil was taken $10 \mathrm{~cm}$ in depth from each plot. Soil was sealed in zip bags and was air dried in the lab at room temperature. For $\mathrm{pH}$ and EC of soil was analyzed in a (1:5) soil: distilled water ratio. Soil was mixed with stirrer and after 30 min reading was recorded by using Jenway $3520 \mathrm{pH}$ meter and Jenway 4150 EC meter, respectively. Organic matter in soil was assessed by following the Estefen et al. (2013) protocol.

\section{Mineral nitrogen $(N)$ and soluble phosphorus $(P)$}

Mineral nitrogen was assessed $\left(\mathrm{NH}_{4}{ }^{+}\right.$and $\left.\mathrm{NO}_{3}\right)$ in soil by following the Sims et al. (1995) protocol, by using a spectrophotometer (Schimazu UV-vis 160) as an alternate of microplate reader. Soluble phosphorus content was assessed by using a spectrophotometer (Schimazu UV-vis 160) and followed the D, Angelo et al. (2001) protocol.

\section{Macro and microaggregates stability}

Soil aggregates were analyzed on the basis of size distribution of soil particles. Stack of sieves were arranged according to the sieves size followed by $2000 \mu \mathrm{m}, 650 \mu \mathrm{m}$, $85 \mu \mathrm{m}, 10.6 \mu \mathrm{m}$. Large sized sieve was set at the top and the smallest sized was set at the bottom of the stack. $20 \mathrm{~g}$ of soil was kept on the top of the stack $(2000 \mu \mathrm{m})$. Stack was immersed carefully in the bucket full of water. Stack was continuously moved up 
and down (jerk) for 30 times within $2 \mathrm{~min}$. Soil on the top of each sieve was collected separately and oven dried at $150{ }^{\circ} \mathrm{C}$ for $24 \mathrm{~h}$ and final reading was recorded (Demisie et al., 2014).

\section{Bacterial diversity}

Whole community of DNA was extracted from $250 \mathrm{mg}$ of fresh soil by using DNeasy PowerSoil ${ }^{\circledR}$ Kit (QIAGEN, Hilden, Germany) through manufacturer's instruction. The DNA was sent to MACROGEN (USA) for sequencing and homology. The primer with the sequence 518F (CCAGCAGCCGCGGTAATACG) and 800R (TACCAGGGTATCTAATCC) were used for the detection of microbes in the soil samples. Obtained sequences were analysed by BLAST (Basal Local Alignment Search Tool) from NCBI. Phylogenetic trees were reconstructed by the neighbour joining method using Editseq (DNASTAR Lasergene; DNASTAR, Madison, WI), Clustal X ver. 1.81 (Thomson et al., 1997) and MEGA ver. 6.0.2 (Tamura et al., 2007).

\section{Statistical analysis}

Data was statistically analyzed by using Minitab18 software for Analysis of variances and LSD.

\section{Results}

\section{Harvest index}

In the first year, yield biomass (pods) was significantly increased in response of control, manure derived biochar applied at the rate of $10 \mathrm{t} \mathrm{ha}^{-1}$, large particles sized wood derived biochar applied at a lower rate of 5 and at a higher rate of $15 \mathrm{t} \mathrm{ha}^{-1}$, however at small particles sized wood derived biochar applied at a lower rate of $5 \mathrm{tha}^{-1}$ as compared to small sized particles applied at a higher rate of 10 and $15 \mathrm{t} \mathrm{ha}^{-1}$ under groundwater. While under wastewater irrigation, there was not any significant difference between the treatments. Besides non-significant differences between the treatments, there was significant differences within the treatments of ground and wastewater irrigation treatments (like, large and small particles sized wood derived biochar applied at lower rate of $5 \mathrm{t} \mathrm{ha}^{-1}$ ). In contrast of the first year, there was not any increase in the yield biomass in the second year under groundwater irrigation. Interestingly, yield biomass was non-significantly increased under groundwater as compared to wastewater irrigation in the second year (Table 3).

In the first year, under groundwater irrigation, aboveground biomass was significantly increased in response of control, manure biochar at lower application rate of $5 \mathrm{t} \mathrm{ha}^{-1}$, large-particle-sized wood biochar at higher rate of $15 \mathrm{t} \mathrm{ha}^{-1}$ and smallparticle-sized wood biochar at lower rate of $5 \mathrm{t} / \mathrm{h}$ than small-particle-sized wood biochar at higher rate of $10 \mathrm{t} \mathrm{ha}^{-1}$; however, aboveground biomass was also increased in response of large-particle-sized wood biochar at $15 \mathrm{t} \mathrm{ha}^{-1}$ and small-particle-sized wood biochar at lower rate of $5 \mathrm{t} \mathrm{ha}^{-1}$ than manure biochar at higher rate of $10,15 \mathrm{tha}^{-1}$, large particle sized wood biochar at higher rate of $10 \mathrm{tha}^{-1}$. In the second year, there was no significant difference of organic amendments than control; however, aboveground biomass was significantly decreased in response of manure biochar at higher application rate of $10 \mathrm{t} \mathrm{ha}^{-1}$ than small-particle-sized wood biochar at higher application rate of $10 \mathrm{t} \mathrm{ha}^{-1}$ (Fig. 2). 
Table 3. Yield biomass/per plot of pea plant during first and second year of the experiment under groundwater and wastewater irrigation treatments

\begin{tabular}{c|c|c|c|c}
\hline \multirow{2}{*}{} & \multicolumn{2}{|c|}{$\mathbf{2 0 1 6}$} & \multicolumn{2}{c}{$\mathbf{2 0 1 7}$} \\
\cline { 2 - 5 } & GW & WW & GW & WW \\
\hline Control & $337.67 \pm 63.08 \mathrm{ab}$ & $254.33 \pm 77.41 \mathrm{ab}$ & $96.33 \pm 4.6 \mathrm{~b}^{*}$ & $44 \pm 10.07 \mathrm{abc}$ \\
BM5 & $299.33 \pm 73.71 \mathrm{abcd}$ & $220.3 \pm 56.62 \mathrm{ab}$ & $238.33 \pm 67.18 \mathrm{ab}^{*}$ & $44 \pm 07.78 \mathrm{ab}$ \\
BM10 & $270.00 \pm 27.01 \mathrm{bc}$ & $296.8 \pm 71.50 \mathrm{ab}$ & $150 \pm 21.92 \mathrm{a}^{*}$ & $46.67 \pm 16.22 \mathrm{abc}$ \\
BM15 & $321.67 \pm 75.67 \mathrm{abcd}$ & $110.46 \pm 36.18 \mathrm{~b}$ & $157.67 \pm 24.06 \mathrm{a}^{*}$ & $40.33 \pm 05.04 \mathrm{bc}$ \\
BW5 & $433.33 \pm 85.39 \mathrm{ab}$ & $256.46 \pm 24.92 \mathrm{a}$ & $258.33 \pm 107.71 \mathrm{ab} *$ & $53.33 \pm 08.69 \mathrm{ab}$ \\
BW10 & $322.67 \pm 62.54 \mathrm{abc}$ & $289.6 \pm 12.88 \mathrm{a}$ & $212 \pm 91.17 \mathrm{ab}$ & $40.67 \pm 06.27 \mathrm{~b}$ \\
BW15 & $414.33 \pm 58.08 \mathrm{a}$ & $208.8 \pm 79.23 \mathrm{ab}$ & $213.67 \pm 70.01 \mathrm{a}^{*}$ & $28.67 \pm 01.51 \mathrm{c}$ \\
(5) BW.65 & $465.67 \pm 25.23 \mathrm{a}^{*}$ & $254.67 \pm 54.05 \mathrm{ab}$ & $237.67 \pm 56.69 \mathrm{a}^{*}$ & $40 \pm 04.49 \mathrm{bc}$ \\
(10)BW.65 & $214.33 \pm 04.27 \mathrm{c}$ & $208.93 \pm 84.48 \mathrm{ab}$ & $262 \pm 33.14 \mathrm{a}^{*}$ & $42.33 \pm 05.52 \mathrm{bc}$ \\
(15) BW.65 & $173.67 \pm 08.11 \mathrm{~d}$ & $390.36 \pm 76.09 \mathrm{a}$ & $142.33 \pm 55.39 \mathrm{ab}$ & $73 \pm 11.08 \mathrm{a}$ \\
\hline
\end{tabular}

Values are mean \pm SE, bars with $*$ represent significant difference between years for a given treatment $(\mathrm{P}<0.05)$, while bars with different letters represent significant difference between treatments of a given year $(\mathrm{P}<0.05)$

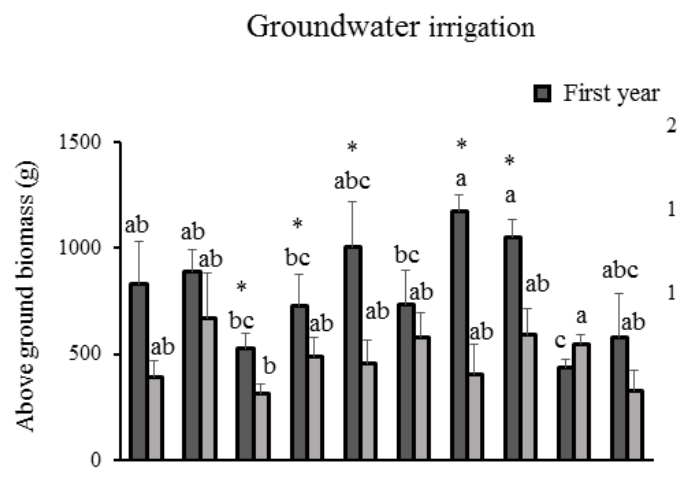

First year
Wastewater irrigation

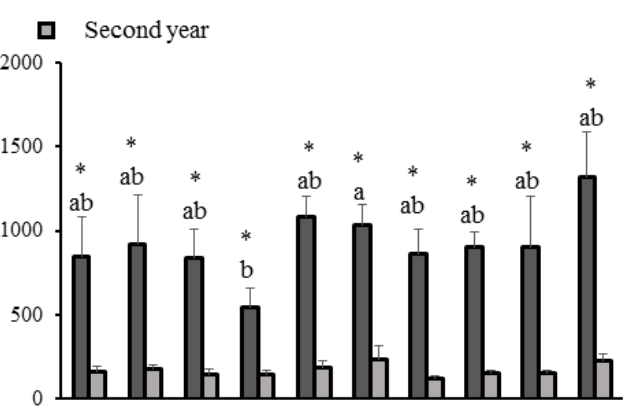

Second year

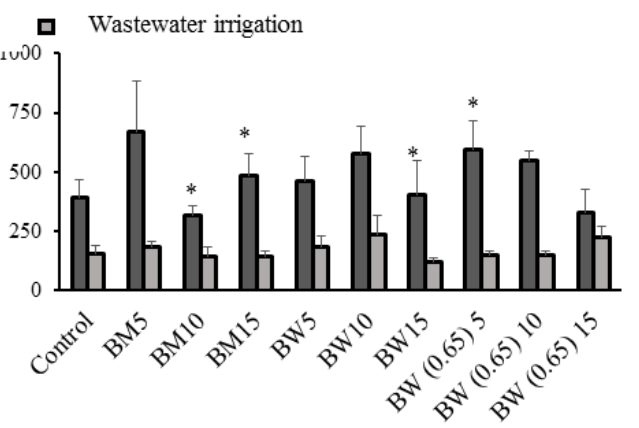

Figure 2. Aboveground biomass $(n=3)$ illustrate difference between treatments within a year and between-year difference of a given treatment, values are mean $\pm S E$, bars with * representing significant difference between years for a given treatment $(P<0.05)$, while bars with different letters represent significant difference between treatments of a given year $(P<0.05), *$ represent difference between irrigation types (groundwater and wastewater) 
In the first year, aboveground biomass was significantly decreased in response of manure derived biochar at higher application rates of $15 \mathrm{t} \mathrm{ha}^{-1}$ than the large-particlesized wood derived biochar amended at higher rate of $10 \mathrm{t} \mathrm{ha}^{-1}$ under wastewater irrigation. In the second year, biochar amendments did not influence aboveground biomass under wastewater irrigation ( $<<0.05$; Fig. 2).

Under both irrigations, there was a significant difference between the first year and the second year. Under groundwater irrigation, in the first year aboveground biomass was significantly higher in response of manure (higher application rate of $10,15 \mathrm{t} \mathrm{ha}^{-1}$ ) and wood biochar (large-particle-sized at higher application rate of $15 \mathrm{t} \mathrm{ha}^{-1}$ and smallparticle-sized at lower application rate of $5 \mathrm{t} \mathrm{ha}^{-1}$ ) than in the second year. Under wastewater irrigation, in the first year, aboveground biomass was higher in response of all organic amendments than in the second year. While, in the first year, there was no difference in aboveground biomass in between both irrigation treatments. While, in the second year, aboveground biomass was significantly higher under groundwater as compared to wastewater irrigation, that increased in aboveground biomass in response of biochar amendments (manure and wood) was the same as observed in between the first year and second year, under groundwater irrigation ( $\mathrm{P}<0.05 ;$ Fig. 2$)$.

In the first year, under groundwater irrigation, harvest index was significantly decreased in response of manure derived at lower application rate of $5 \mathrm{t} \mathrm{ha}^{-1}$ than manure biochar at a higher rate of $10,15 \mathrm{t} \mathrm{ha}^{-1}$ and large-particle-sized wood biochar at a higher rate of $10,15 \mathrm{t} \mathrm{ha}^{-1}$. In the second year, biochar did not influence the harvest index under groundwater irrigation; manure biochar at rate of $10 \mathrm{t} \mathrm{ha}^{-1}$ has significantly increased harvest index than at rate of $15 \mathrm{t} \mathrm{ha}^{-1}$. While under wastewater irrigation, no biochar influence was observed for both years (Fig. 3). Harvest index increased in the first year as compared to the second year in control than in all other organic amendments; in contrast, increase was observed in response of large-particle-sized wood biochar in the second year as compared to first year under groundwater irrigation. While, there was no significant difference in between the first and the second year under wastewater irrigation. In the first year, there was a significant difference in between all treatments, except for manure biochar at a lower rate of $5 \mathrm{t} \mathrm{ha}^{-1}$ and small and largeparticle-sized wood biochar at a higher rate of $15 \mathrm{t} \mathrm{ha}^{-1}$ (Fig. 3).

\section{Ph, EC and organic matter in soil}

Under both irrigation treatments, biochar amendments did not influence the soil $\mathrm{pH}$, as well as did not have significant difference in between both irrigation treatments. Under groundwater irrigation, there was no significant influence of biochar on EC; however significantly the highest increase was observed in response of manure biochar at/higher rate of $10 \mathrm{t} \mathrm{ha}^{-1}$ than large-particle-sized wood biochar at lower rate of $5 \mathrm{t} \mathrm{ha}^{-1}$. Under wastewater irrigation, EC was significantly increased in response of smallparticle-sized wood biochar at lower rate of $5 \mathrm{t} \mathrm{ha}^{-1}$ than large-particle-sized wood biochar at higher rate of $10 \mathrm{t} \mathrm{ha}^{-1}$. EC was significantly different in between groundwater and wastewater, this influence was followed in response of manure biochar at higher rate of $15 \mathrm{t} \mathrm{ha}^{-1}$, large-particle-sized wood biochar at lower $\left(5 \mathrm{t} \mathrm{ha}^{-1}\right)$ and higher rate $\left(15 \mathrm{t} \mathrm{ha}^{-1}\right)$ and small-particle-sized at higher rate of $10 \mathrm{tha}^{-1}$. EC was higher in wastewater than in groundwater irrigation (Table 4). Interactions between irrigation type and biochar types were significant for soil EC $(\mathrm{P}<0.05$; Table 4). 
Table 4. Mean $\pm S D$ of $p H, E C(\mu s)$, organic matter (\%), mineral $N(\%)$, soluble mineral $P$, total $C$ and total $N$ in soil under groundwater $(G W)$ and wastewater $(W W)$ irrigation

\begin{tabular}{|c|c|c|c|c|c|c|c|c|c|c|c|c|}
\hline \multirow{2}{*}{ Treatments } & \multicolumn{2}{|c|}{ pH } & \multicolumn{2}{|c|}{ EC } & \multicolumn{2}{|c|}{ Organic matter } & \multicolumn{2}{|c|}{ N\% } & \multicolumn{2}{|c|}{$\mathrm{C \%}$} & \multicolumn{2}{|c|}{ C:N } \\
\hline & GW & WW & GW & WW & GW & WW & GW & WW & GW & WW & GW & WW \\
\hline Control & $9.26 \pm 0.17$ & $8.90 \pm 0.04$ & $495.00 \pm 142.1 \mathrm{ab}$ & $459.00 \pm 35.83 \mathrm{ab}$ & $14.20 \pm 1.92 b^{*}$ & $26.25 \pm 1.19 \mathrm{c}$ & 0.11 & 0.18 & 2.68 & 3.14 & 24.59 & 17.52 \\
\hline BM5 & $9.63 \pm 0.10$ & $8.76 \pm 0.09$ & $411.33 \pm 57.15 \mathrm{ab}$ & $652.00 \pm 55.89 \mathrm{ab}$ & $16.92 \pm 1.31 b^{*}$ & $25.68 \pm 0.26 \mathrm{c}$ & 0.13 & 0.17 & 2.9 & 2.89 & 22.16 & 16.76 \\
\hline BM10 & $9.50 \pm 0.04$ & $8.83 \pm 0.05$ & $551.00 \pm 71.00 \mathrm{a}$ & $552.33 \pm 176.35 \mathrm{ab}$ & $16.32 \pm 1.82 b^{*}$ & $21.59 \pm 1.63 \mathrm{c}$ & 0.11 & 0.14 & 2.93 & 2.84 & 27.12 & 20.93 \\
\hline BM15 & $9.70 \pm 0.07$ & $8.93 \pm 0.02$ & $312.33 \pm 32.33 b^{*}$ & $478.33 \pm 39.21 \mathrm{ab}$ & $29.21 \pm 12.97 \mathrm{ab}$ & $25.13 \pm 2.01 b c$ & 0.12 & 0.16 & 2.96 & 3.05 & 23.86 & 18.87 \\
\hline BW5 & $9.50 \pm 0.09$ & $8.67 \pm 0.15$ & $284.67 \pm 30.11 b^{*}$ & $541.67 \pm 27.85 \mathrm{ab}$ & $21.32 \pm 2.51 \mathrm{ab}^{*}$ & $38.47 \pm 2.35 \mathrm{a}$ & 0.15 & .2 & 3.24 & 3.32 & 21.07 & 16.76 \\
\hline BW10 & $9.23 \pm 0.30$ & $8.93 \pm 0.02$ & $420.67 \pm 123.0 \mathrm{ab}$ & $456.67 \pm 64.29 b$ & $22.83 \pm 2.13 \mathrm{ab}^{*}$ & $39.34 \pm 1.13 \mathrm{a}$ & 0.12 & 0.17 & 3.29 & 3.45 & 28.29 & 19.81 \\
\hline BW15 & $9.46 \pm 0.19$ & $8.83 \pm 0.02$ & $392.00 \pm 41.68 \mathrm{ab}^{*}$ & $593.00 \pm 55.89 \mathrm{ab}$ & $29.54 \pm 2.73 \mathrm{a}^{*}$ & $51.74 \pm 5.63 \mathrm{a}$ & 0.12 & 0.12 & 3 & 3.11 & 25.73 & 25.59 \\
\hline $\mathrm{BW}(0.65) 5$ & $9.36 \pm 0.19$ & $8.86 \pm 0.05$ & $397.67 \pm 72.52 \mathrm{ab}$ & $512.67 \pm 11.93 \mathrm{ab}$ & $18.98 \pm 1.99 \mathrm{a}^{*}$ & $28.72 \pm 2.14 \mathrm{c}$ & 0.1 & 0.18 & 2.9 & 3.41 & 28.03 & 18.92 \\
\hline $\mathrm{BW}(0.65) 10$ & $9.30 \pm 0.14$ & $8.96 \pm 0.02$ & $391.00 \pm 78.84 \mathrm{ab}^{*}$ & $680.00 \pm 70.76 a$ & $20.49 \pm 4.54 \mathrm{ab}$ & $39.21 \pm 4.92 \mathrm{ab}$ & 0.17 & 0.21 & 4.78 & 3.41 & 28.95 & 16.15 \\
\hline $\mathrm{BW}(0.65) 15$ & $9.43 \pm 0.19$ & $8.86 \pm 0.02$ & $540.00 \pm 82.67 \mathrm{a}$ & $571.00 \pm 54.26 \mathrm{ab}$ & $27.56 \pm 1.08 \mathrm{a}^{*}$ & $34.99 \pm 4.28 \mathrm{ab}$ & 0.15 & 0.21 & 3.6 & 4.33 & 24.03 & 20.85 \\
\hline
\end{tabular}

Values are mean $\pm \mathrm{SE}$ and bars with different letters represent significant differences in between treatments of a given year and $*$ represents significant differences in between the irrigation treatments $(\mathrm{P}<0.05)$

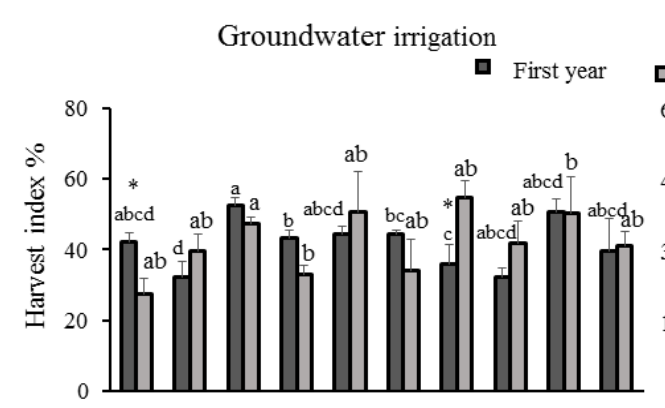

First year

口 Groundwater irrigation

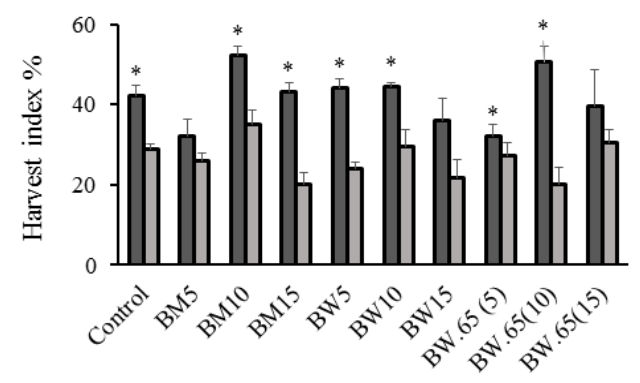

Wastewater irrigation

Second year

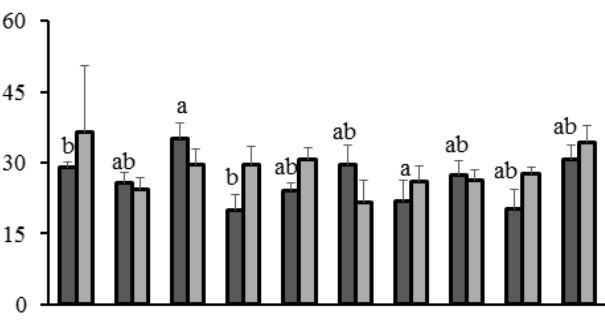

Second year

ㅁ Wastewater irrigation

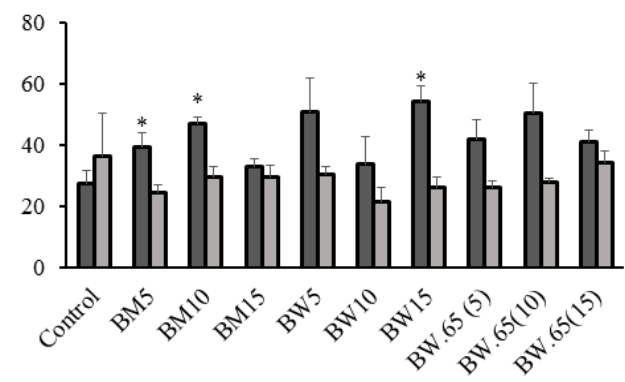

Figure 3. Harvest index $(n=3)$ illustrates difference between treatments within year and between-year difference of a given treatment, values are mean $\pm S E$, bars with * representing significant difference between years for a given treatment $(P<0.05)$, while bars with different letters represent significant difference between treatments of a given year $(P<0.05)$, * represents difference between irrigation types (groundwater and wastewater) $(P<0.05)$

Under groundwater irrigation, biochar did not have influence on soil organic matter; however, the highest increase was observed in response of large-particle-sized wood biochar at higher rate of $15 \mathrm{t} \mathrm{ha}^{-1}$ than the control and manure biochar at lower and higher rate of $5 \mathrm{tha}^{-1}$, $10 \mathrm{t} \mathrm{ha}^{-1}$, respectively. Under wastewater irrigation, significantly the highest increase was in response of large-particle-sized wood biochar at higher rate of $15 \mathrm{t} \mathrm{ha}^{-1}$ than the lowest in response of small-particle-sized wood biochar at lower rate of $5 \mathrm{t} \mathrm{ha}^{-1}$. Significant differences 
between groundwater and wastewater irrigation were in response of control, manure biochar at lower $\left(5 \mathrm{tha}^{-1}\right)$ and higher rate $\left(10 \mathrm{tha}^{-1}\right)$ and including all treatments of wood biochar except small-particle-sized wood biochar at higher rate of $10 \mathrm{t} \mathrm{ha}^{-1}$. As compared to groundwater, wastewater has maximum increased in organic matter (Table 4).

Finally, wastewater irrigation with biochar amendments has a more positive influence on $\mathrm{EC}$ and organic matter than soil $\mathrm{pH}$. $\mathrm{C}$ and $\mathrm{N}$ concentrations were higher in response of wastewater irrigation than the groundwater irrigation but in contrast, $\mathrm{C}: \mathrm{N}$ ratio was higher in response of groundwater irrigation than the wastewater irrigation. These results are based on pooled soil samples; although, $\mathrm{C}$ and $\mathrm{N}$ concentrations were higher in response of wood derived biochar than the manure derived biochar under both irrigations than the control $(\mathrm{P}<0.05 ;$ Table 4).

\section{Mineral nitrogen (N) and soluble phosphorus $(P)$}

Under groundwater irrigation, soluble phosphorus $(\mathrm{P})$ was significantly higher in response of manure derived biochar at higher rate of $15 \mathrm{tha}^{-1}$, lower rate of $5 \mathrm{t} \mathrm{ha}^{-1}$ and large sized wood derived biochar at higher rate of $15 \mathrm{t} \mathrm{ha}^{-1}$ than control respectively; amongst all the treatments manure derived at higher of $15 \mathrm{t} \mathrm{ha}^{-1}$ had profound influence. While, under wastewater irrigation biochar did not influence $\mathrm{P}$ in soil; there was significant difference between both irrigation treatments like, control, wood derived biochar at all its application rates $(5,10$ and 15 $\mathrm{t} \mathrm{ha}^{-1}$ ) and small particle sized wood derived biochar at 5 and $10 \mathrm{t} \mathrm{ha}^{-1}$. In contrast of $\mathrm{P}$, nitrogen $(\mathrm{N})$ was significantly higher under wastewater irrigation (Fig. 4). However under groundwater irrigation $\mathrm{P}$ was significantly higher in response of manure derived biochar at higher rate of 15 than control and under wastewater irrigation $\mathrm{N}$ was decreased in response of manure derived biochar at higher rate of $15 \mathrm{t} \mathrm{ha}^{-1}$ than control, manure derived biochar at lower rate of $5 \mathrm{t} \mathrm{ha}^{-1}$, large sized particle of wood derived biochar at the application rate of 10, $15 \mathrm{tha}^{-}$ ${ }^{1}$ and small sized wood derived biochar amendments at lower and higher rate of 5, $10 \mathrm{t} \mathrm{ha}$, respectively. There was significant difference between both irrigation treatments except manure derived biochar at lower rate of $5 \mathrm{t} \mathrm{ha}^{-1}$ and small sized wood derived biochar at lower rate of $5 \mathrm{t} /$ ha and higher rate of $15 \mathrm{tha}^{-1}$.

\section{Macro and microaggregates stability}

Under groundwater irrigation, for $2000 \mu \mathrm{m}$ aggregates stability was significantly increased in response of small-particle-sized wood biochar at higher rate than manure biochar at lower (5 $\left.\mathrm{t} \mathrm{ha}^{-1}\right)$ and higher rate $\left(15 \mathrm{t} \mathrm{ha}^{-1}\right)$, large-particle-sized wood biochar at higher rate of 10 ha- $^{-1}$. For 2000-650 $\mu \mathrm{m}$ aggregates stability was significantly decreased in response of large-particlesized wood biochar at higher rate of $10 \mathrm{t} \mathrm{ha}^{-1}$ than control. For $650-85 \mu \mathrm{m}$ aggregates stability was significantly decreased in response of large-particle-sized wood biochar at higher rate of $10 \mathrm{t} / \mathrm{h}$ than manure biochar at lower rate of $5 \mathrm{t} \mathrm{ha}^{-1}$ and there was no significant influence of biochar for $85-10.6 \mu \mathrm{m}$ aggregates stability. Under wastewater irrigation, for $2000 \mu \mathrm{m}$ aggregates stability was significantly increased in response of manure biochar at lower rate of $5 \mathrm{t} \mathrm{ha}^{-1}$ than manure biochar at higher rate of $10,15 \mathrm{t} \mathrm{ha}^{-1}$ and small-particle-sized wood biochar at lower rate of $5 \mathrm{t} \mathrm{ha}^{-1}$. For $650-85 \mu \mathrm{m}$ aggregates, stability was significantly decreased in response of manure biochar at lower rate of $5 \mathrm{t} \mathrm{ha}^{-1}$ than control, manure biochar at higher rate of $10,15 \mathrm{tha}^{-1}$. However, large-particle-sized wood biochar at higher rate of $10 \mathrm{t}$ $\mathrm{ha}^{-1}$ and for $85-10.6 \mu \mathrm{m}$ aggregates stability significantly increased in response of manure biochar at higher rate of $10 \mathrm{tha}^{-1}$ than manure biochar at higher rate, small-large-particle-sized wood biochar at higher rate of 15 and $10 \mathrm{tha}^{-1}$, respectively (Fig. 5). 


$$
-2120 \text { - }
$$
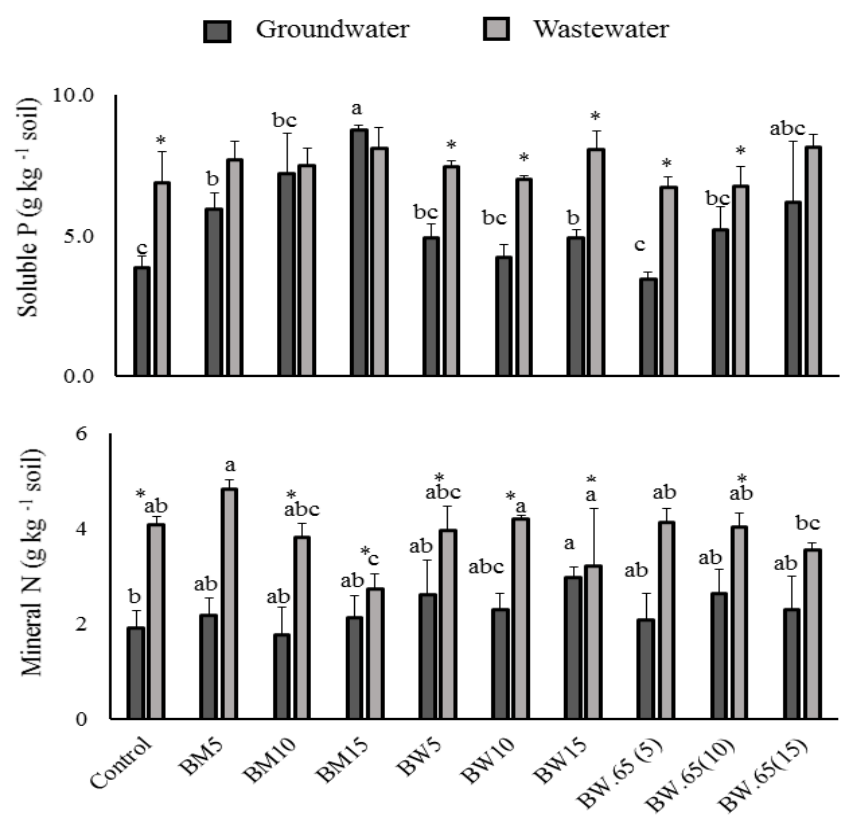

Figure 4. Soluble phosphorus and Mineral nitrogen in soil $(n=3)$ under-ground and waste water irrigation treatments. Values are mean $\pm S E$, Bars with different letters represent significant difference between organic amendment treatments of a given irrigation treatment while * represents differences between irrigation treatments (groundwater vs wastewater)
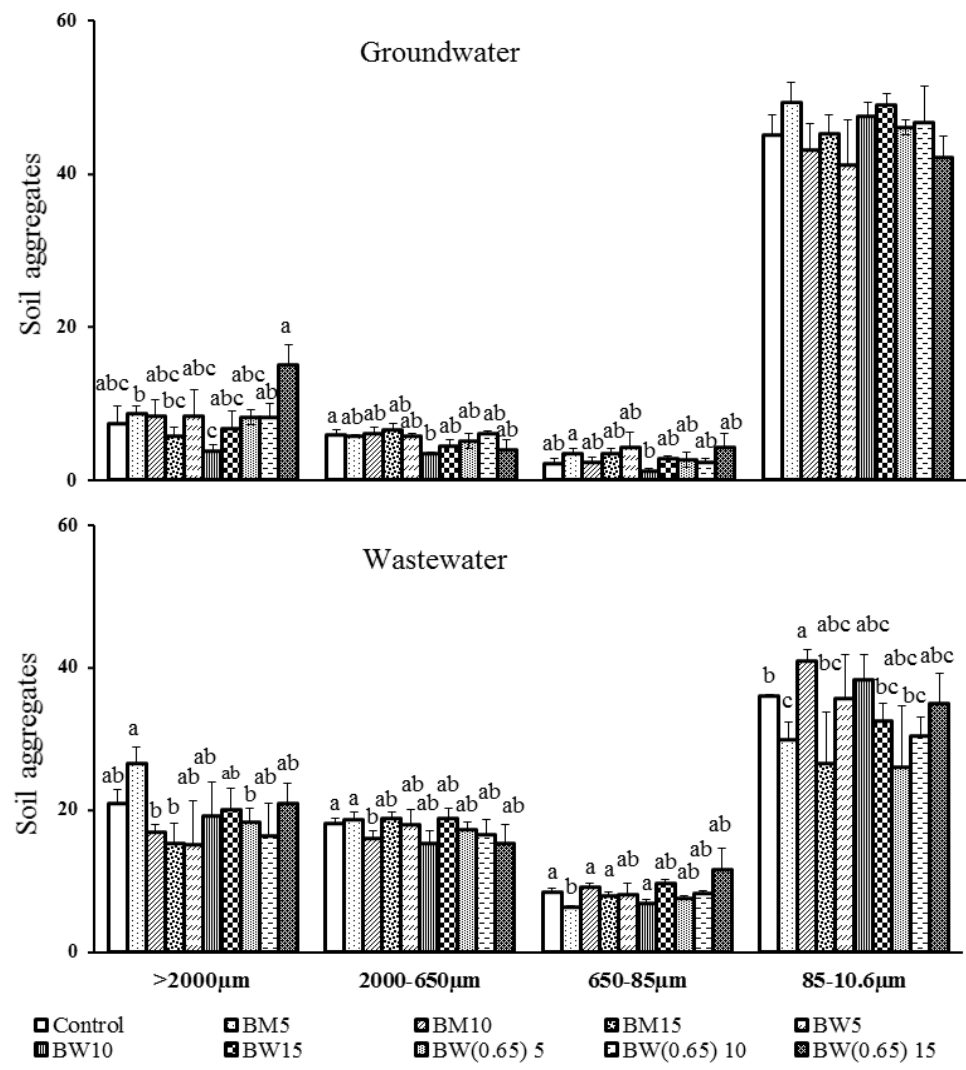

Figure 5. Soil aggregates of various sizes of soils under groundwater and wastewater irrigation. Values are mean $\pm S E$ and bars with different letters represent significant difference between treatments of a given year $(P<0.05)$ 
However, macroaggregates stability $(2000 \mu \mathrm{m})$ was significantly different in between the groundwater and wastewater irrigation except in response of large-particlesized wood biochar at lower rate of $5 \mathrm{t} \mathrm{ha}^{-1}$, small-particle-sized wood biochar at higher rate of 10 and $15 \mathrm{t} \mathrm{ha}^{-1}$; however, wastewater has higher aggregates stability for macroaggregates than the groundwater (Fig. 6).

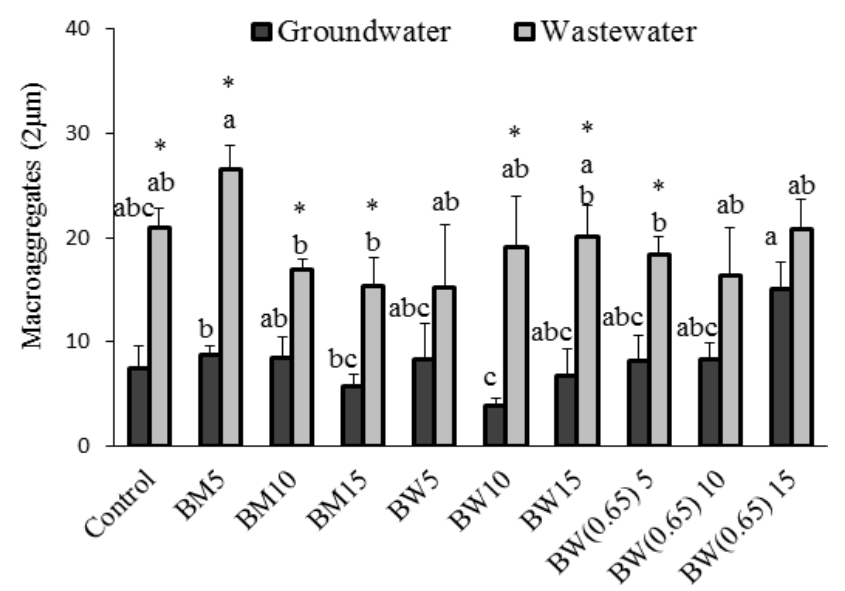

Figure 6. Macroaggregates in soil $(n=3)$ under-ground and waste water irrigation treatments. Values are mean $\pm S E$, Bars with * represent the difference within irrigation treatments $(P<0.05)$

\section{Bacterial diversity}

Two phylogenetic trees describe the bacterial diversity under groundwater and wastewater irrigation (Fig. 7). These results are based on pooled soil samples; however, number of bacterial genera are two-fold higher in the soil samples from groundwater irrigation treatment as compared to the soil samples from wastewater irrigation treatment. Under groundwater, phylogenetic tree indicates the presence of three bacterial genera i.e., Vibrio, Tepidamorphus gemmatus and Brevundimonas diminuta. Under wastewater irrigation, phylogenetic tree indicates the presence of three species that belong to the genera Vibrio i.e., $V$. parahaemolyticus, $V$. alginolyticus and $V$. campbelli (Fig. 8).

\section{Discussion}

\section{Harvest index of yield}

In the first year, under groundwater irrigation, yield biomass and aboveground biomass significantly decreased due to higher surface area of small-particle-sized wood biochar that has the highest adsorption capacity of nutrients at higher application rate $\left(10 \mathrm{t} \mathrm{ha}^{-1}\right)$, this might have reduced the nutrients availability and in contrast, lower application rate have significantly increased the aboveground biomass (Manzoor et al., 2019). However, the influence of small-particle-sized wood derived biochar at higher application rate was inconsistent for the first and second year. In the first year, nutrients availability decreased by adhering the nutrients with biochar surface area, however in the second year, continuous biochar amendments have increased the free nutrients availability for the crop more than the first year. While in the second year, aboveground 
biomass was decreased in response of manure biochar at higher application rate of $10 \mathrm{t} \mathrm{ha}^{-1}$. Manure biochar is the rich source of nutrients than the other biochar types, for this, continuous amendments of biochar built up the osmotic pressure on roots reduced the aboveground biomass (Manzoor et al., 2019). In response of second year, decrease in yield was not in favor of previous empirical reports of our finding that biochar amendments increase the crop production (Gul and Whalen, 2016; Rawat et al., 2019).

Groundwater

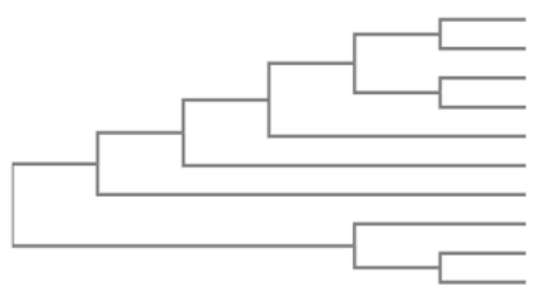

f1-Vibrio-parahaemolyticus-KY495 0.00520833 f2-Vibrio-natriegens-KY790454 se 0.00520833 f4-Vibrio-diabolicus-JX257007 se 0.00720165 f5-Vibrio-alginolyticus-MF692783 0.00720165 f3-Vibrio-alginolyticus-KU891054 0.0120594 f6-Vibrio-natriegens-KY790452.se 0.0158507 f7-Vibrio-alginolyticus-MF683843 0.0165222 f9-Tepidamorphus-gemmatus-NR1174 0.0472599 f8-Vibrio-alginolyticus-EU155510 0.0315789 f10-Brevandimonas-diminuta-KT025 0.0315789

Wastewater

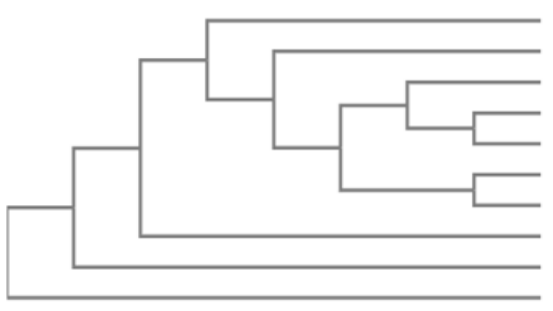

s7-Vibrio-alginolyticus-JF700503 0.00767963 s10-Vibrio-parahaemolyticus-MF94 0.00684177 s6-Vibrio-alginolyticus-MF692785 0.00270505 s5-Vibrio-parahaemolyticus-NR119 0.000535906 s8-Vibrio-campbellii-MH135321.se 0.000535906 s9-Vibrio-parahaemolyticus-MG952 0.00210748 s1-Vibrio-alginolyticus-MK308611 0.00210748 s4-Vibrio-alginolyticus-NR119049 0.00901127 s3-Vibrio-alginolyticus-MG952585 0.00975031 s2-Vibrio-parahemolyticus-KF1549 0.0130761

$\mathrm{S}=$ sewage, $\mathrm{F}=$ fresh (1: control, 2: BM5,3: BM 10,4: BM15, 5: BW5, 6: BW 1 7: BW15, 8: BW (0.65) 5, 9: BW (0.65) 10, 10: BW (0.65) 15)

Figure 7. Phylogenetic tree of the microbial structure present in soil under groundwater and wastewater irrigation

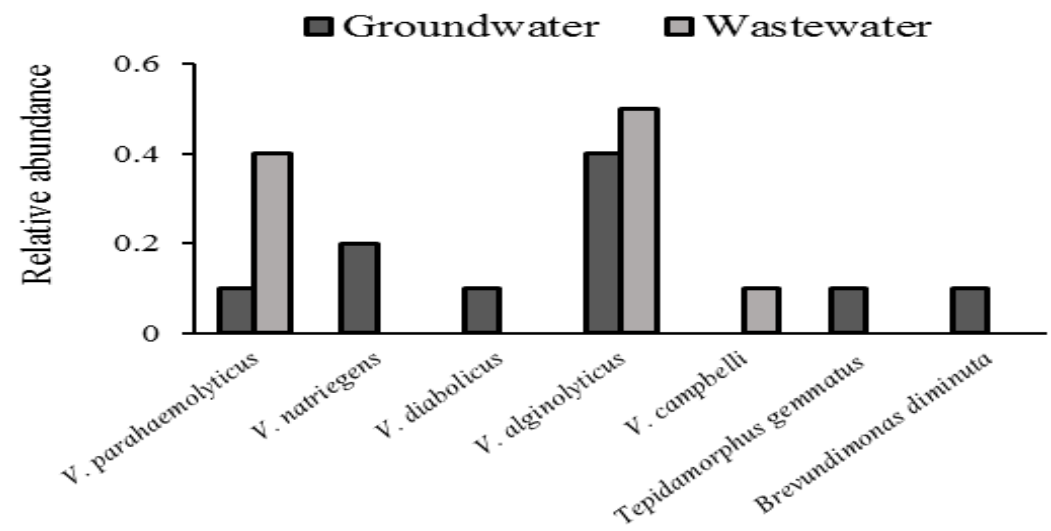

Figure 8. Relative abundance of microorganisms underground and wastewater irrigation in response of biochar amendments

In the first year, under wastewater irrigation, aboveground biomass was significantly decreased in response of higher application rate than large-particle-sized wood derived biochar. Interestingly, our findings are in favor of Manzoor et al. (2019) report for in 
response of organic amendments (decrease in manure derived at high application rate of $15 \mathrm{t} \mathrm{ha}^{-1}$, increase in large particle-sized wood derived biochar at high application rate of $10 \mathrm{t} \mathrm{ha} \mathrm{ha}^{-1}$ ) under wastewater irrigation; however large-particle-sized have less adsorption capacity than the small particle sized, this increase in nutrients availability have positive influence on aboveground biomass. Despite the wastewater, is a rich source of nutrients the yield reduced in response of biochar amendments.

Possible explanation of decrease in harvest index, under groundwater irrigation is that manure and wood biochar at higher rate adhere the trace elements with biochar surface (Haider et al., 2019); while under wastewater irrigation, this results in profound negative influence on crop yield. Harvest index was significantly higher as compared to wastewater, under groundwater irrigation; however, profound influence of biochar might be suppressed in response of non-pyrogenic organic amendments with biochar amendments of manure at application rate of $5 \mathrm{t} \mathrm{ha}^{-1}$ (Bonanomi et al., 2017). Interestingly, Kammann et al. (2016) reported that influence of biochar and nonpyrogenic organic matter amendments have very few studies and merits further evaluation. In contrast, in the second year, as compared to wastewater, under groundwater irrigation harvest index was not significantly different in between the treatments except for manure derived biochar at higher rate of $5,10 \mathrm{t} \mathrm{ha}^{-1}$, largeparticle-sized wood derived biochar at higher rate of $15 \mathrm{t}$ ha ${ }^{-}$. Overburden of biochar have negative influence on crop production; continuous amendments of biochar did not have positive influence in the second year than first year on aboveground biomass and harvest index. Our findings are in agreement of previous literature that groundwater irrigation have more positive influence on the following crops; pea plant and maize (Mensah and Frimpong (2018); Manzoor et al., 2019) respectively. Although wastewater is reported to improve soil quality, very few studies reported biochar responses under wastewater irrigation. This merits further long-term experiments to understand the influence of biochar under wastewater irrigation and impact on crops yield.

\section{Ph, EC and organic matter in soil}

In case of $\mathrm{pH}$, our findings are not in agreement with Dume et al. (2016); Hameeda et al. (2019) reported that biochar have positive influence and are in agreement of other empirical reports that organic amendments did not have influence (Abrishamkesh et al., 2015) on soil; however, have negative influence ( $\mathrm{Gul}$ et al., 2015) on pH in alkaline soil (Table 2). Rather than alkaline soil, biochar amendments reported for positive influence on soil $\mathrm{pH}$ under acidic soil. While, an increase in EC is related to the nutrients availability in soil under wastewater irrigation treatment; for this, EC was increased in response of biochar amendments at higher rate by increasing available nutrients adsorption. As a result, biochar amendments have a more positive influence for an increase in EC under wastewater irrigation than ground water. Increase in total dissolved solids in wastewater increase EC. An increase in $\mathrm{pH}$ and EC based on physical and chemical properties of biochar type; like, Chintala et al. (2013) reported that corn biochar (stover) have higher increase in $\mathrm{pH}$ than switchgrass biochar at all biochar amendments. EC and organic matter was increased in response of wood derived biochar at higher rate of $\left(15 \mathrm{t} \mathrm{ha}^{-1}\right)$ than the manure biochar. Higher rate of biochar amendments increases the release of free cation and anions in the soil, which results in an increase in EC (Reeve et al., 2016); biochar have positive influence on EC and organic matter in response of wood biochar at higher rate on EC and organic matter in soil. 
In results of pooled soil samples, higher $C$ under wastewater irrigation favors the indirect increase of organic matter and promote macroaggregates stability in biochar amended soil. Increase in organic matter favors the formation of macroaggregates in response of higher microbial diversity in soil. Our findings are against of Beidermen and Harpole (2012) findings that $\mathrm{C}$ : $\mathrm{N}$ ratio did not have pronounced influence crop productivity: interestingly, more extensive research is required to evaluate the biochar influence on $\mathrm{C}$ : $\mathrm{N}$ ratio. Finally, wastewater irrigation with biochar amendments have favored the increase in soil $\mathrm{EC}$, organic matter and $\mathrm{C} \%$ and $\mathrm{N} \%$.

\section{Mineral nitrogen $(N)$ and soluble phosphorus $(P)$}

Possible increase in $\mathrm{P}$ in response of manure derived biochar at higher rate of $15 \mathrm{t} / \mathrm{ha}$ than control might be that manure is richer source of nutrients than wood derived biochar, so this favors the increase in $\mathrm{P}$ content under groundwater irrigation; as compared to ground water, wastewater irrigation has higher content of $\mathrm{P}$ at higher rates of all biochar amendments. Because, wood derived biochar at higher rate had positive influence on $\mathrm{P}$ in response of rich organic matter irrigation treatment (wastewater).

Under wastewater irrigation, $\mathrm{N}$ was significantly higher in response of manure derived biochar at lower rate of $5 \mathrm{tha}^{-1}$ than the higher rate of $15 \mathrm{t} \mathrm{ha}^{-1}$. Rich source of nutrients in response of manure under wastewater irrigation has balanced more at lower rate than at the higher rate. While, second reason might be in response of available $\mathrm{P}$ and $\mathrm{N}$ content in biochar amended treatments and air-dried cow manure. For $\mathrm{P}$, manure biochar and dried cow manure amendments were higher in $\mathrm{P}$ than the wood derived biochar. However, manure biochar and dried cow manure had higher $\mathrm{N}$ than the wood derived biochar. So, manure derived biochar response was profound for $\mathrm{N}$ and $\mathrm{P}$ availability in soil under both irrigation treatments than the wood derived biochar.

Finally, current findings are inconsistent with previous work that organic amendments increase mineral $\mathrm{N}$ and soluble $\mathrm{P}$ content in soil (Clough et al., 2013; Ameloot et al., 2015) but wastewater has high content of nutrients in response to biochar amendments and more increased $\mathrm{N}$ and $\mathrm{P}$ availability in soil than groundwater. This merits further research to understand biochar influence under wastewater irrigation with different soil types. Biochar amendments, reported for positive influence on the soluble phosphorus and nitrogen in soil (Nelson et al., 2017; Singh et al., 2018).

\section{Macro and microaggregates stability}

Soil organic matter improves the soil aggregates stability. In our findings, soil organic matter was higher in wastewater than in groundwater as a result aggregates stability was high under wastewater irrigation. Biochar has positive influence on soil organic matter and water saturation, this interaction favors the soil aggregates stability (Ouyang et al., 2013). In our findings, amendments of biochar has significant influence for macroaggregates $(>200 \mu \mathrm{m})$ under wastewater irrigation (Fig. 5). Therefore, it appears that biochar has potential to improve the soil aggregates stability (Olmo et al., 2014; Gul et al., 2015). These findings merit further to evaluate association between biochar types at different rate and soil types (Herath et al., 2013; Nelison et al., 2014).

\section{Bacterial diversity}

Despite of significantly higher water-stable soil macroaggregates, with significantly higher concentration of mineral $\mathrm{N}$ and soluble mineral $\mathrm{P}$, wastewater-irrigated soil had 
lower bacterial diversity as compared to groundwater irrigation. The electrical conductivity of wastewater-irrigated soil was in general higher than that of groundwater-irrigated soil, high concentration of nutrients and high electrical conductivity might have had a negative influence on microbial diversity. More extensive research is required to evaluate microbial abundance and diversity as influenced by wastewater-irrigation-induced high concentration of nutrients in soil and to link microbial properties to crop yield.

\section{Conclusion}

Contrary to present hypotheses, wastewater irrigation did not improve harvest index of pea as compared to groundwater irrigation and amendment of biochars in general did not cause a positive influence on pea growth and soil quality. Although, soil under two years of wastewater irrigation had significantly stronger macroaggregates, higher concentration of mineral $\mathrm{N}$ but soluble $\mathrm{P}$ was higher under groundwater irrigation, groundwater irrigated soil had 2-fold higher number of bacterial genera than the soil under wastewater irrigation. Lower bacterial diversity in wastewater-irrigated soil can be a reason of lower harvest index of plants as compared to groundwater irrigation. Further research is required to evaluate the influence of wastewater-irrigation-induced high level of nutrients and electrical conductivity on soil microbial abundance and diversity and to link microbial properties to crop yield (Tóthmérész, 1995).

\section{REFERENCES}

[1] Abrishamkesh, S., Gorji, M., Asadi, H., Bagheri-Marandi, G. H., Pourbabaee, A. A. (2015): Effects of rice husk biochar application on the properties of alkaline soil and lentil growth. - Plant Soil Environment 61: 475-482.

[2] Ahmad, S., Islam, M. (2011): Rangeland Productivity and Improvement Potential in Highlands of Balochistan, Pakistan. - In: Matovic, M. D. (ed.) Biomass - Detection, Production and Usage. IntechOpen, London, pp. 289-304.

[3] Akoto-Danso, E. K., Manka'abusi, D., Steiner, C., Werner, S., Häring, V., Nyarko, G., Marschner, B., Drechsel, P., Buerkert, A. (2018): Agronomic effects of biochar and wastewater irrigation in urban crop production of Tamale, northern Ghana. - Nutrient Cycling Agroecosystem 115: 231-247.

[4] Ameloot, N., Sleutel, S., Das, K. C., Kanagaratnam, J., De Neve, S. (2015): Biochar amendment to soils with contrasting organic matter level: effects on $\mathrm{N}$ mineralization and biological soil properties. - GCB Bioenergy 7: 135-144.

[5] Biederman, L. A., Harpole, W. S. (2012): Biochar and its effects on plant productivity and nutrient cycling: a meta-analysis. - GCB Bioenergy 5: 202-214.

[6] Bonanomi, G., Ippolito, F., Cesarano, G., Nanni, B., Lombardi, N., Rita, A., Saracino, A., Scala, F. (2017): Biochar as plant growth promoter: better off alone or mixed with organic amendments? - Frontier in Plant Sciences 8: 1570.

[7] Chintala, R., Mollinedo, J., Schumacher, T. E., Malo, D. D., Julson, J. L. (2014): Effect of biochar on chemical properties of acidic soil. - Archives of Agronomy and Soil Sciences 60: 393-404.

[8] Clough, T. J., Condron, L. M., Kammann, C., Müller, C. (2013): Review of biochar and soil nitrogen dynamics. - Journal of Agronomy 3: 275-293.

[9] D’Angelo, E., Crutchfield, J., Vandiviere, M. (2001): Rapid, sensitive, microscale determination of phosphate in water and soil. - Journal of Environmental Quality 30: 2206-2209. 
[10] Demisie, W., Liu, Z., Zhang, M. (2014): Effect of biochar on carbon fractions and enzyme activity of red soil. - Catena 121: 214-221.

[11] Dume, B., Mosissa, T., Nebiyu, A. (2016): Effect of biochar on soil properties and lead $(\mathrm{Pb})$ availability in a military camp in South West Ethiopia. - African Journal of Environmental Sciences and Technology 10: 77-85.

[12] Elgallal, M., Fletcher, L., Evans, B. (2016): Assessment of potential risks associated with chemicals in wastewater used for irrigation in arid and semiarid zones: a review. Agricultural Water and Management 177: 419-431.

[13] Estefan, G., Sommer, R., Ryan, J. (2013): Methods of Soil, Plant, and Water Analysis. A Manual for the West Asia and North Africa Region. - ICARDA, Beirut, pp. 170-176.

[14] Government of Pakistan (2018): Fruit, Vegetables and Condiments Statistics of Pakistan. - Agriculture and Livestock; Economic Wing, Islamabad.

[15] Gul, S., Whalen, J. K. (2016): Biochemical cycling of nitrogen and phosphorus in biochar-amended soils. - Soil Biology and Biochemistry 103: 1-15.

[16] Gul, S., Whalen, J. K., Thomas, B. W., Sachdeva, V., Deng, H. (2015): Physico-chemical properties and microbial responses in biochar-amended soils: mechanisms and future directions. - Agricultural Ecosystem and Environment 206: 46-59.

[17] Haider, F., Gul, S., Hussain, J., Ghori, S. A., Shahwani, M. N., Murad, M., Kakar, A. M. (2018): Influence of biochar on yield and heavy metal accumulation in roots of Brassica rapa under groundwater and wastewater irrigation. - Sarhad Journal of Agriculture (SJA) 34: $1-10$

[18] Hameeda., Gul, S., Bano, G., Manzoor, M., Chandio, T. A., Awan, A. A. (2019): Biochar and manure influences tomato fruit yield, heavy metal accumulation and concentration of soil nutrients under groundwater and wastewater irrigation in arid climatic conditions. Cogent Food and Agriculture 5: 1-15.

[19] Herath, H. M., Camps-Arbestain, M., Hedley, M. (2013): Effect of biochar on soil physical properties in two contrasting soils: an Alfisol and an Andisol. - Geoderma 209: 188-197.

[20] Jeffery, S., Verheijen, F. G., van der Velde, M., Bastos, A. C. (2011): Quantitative review of the effects of biochar application to soils on crop productivity using meta-analysis. Agricultural Ecosystem and Environment 144: 175-187.

[21] Kammann, C., Glaser, B., Schmidt, H. P. (2016): Combining Biochar and Organic Amendments. - In: Shackley, S. et al. (eds.) Biochar in European Soils and Agriculture. Science and Practice. Routledge, London, pp.136-164.

[22] Kamran, M., Malik, Z., Parveen, A., Huang, L., Riaz, M., Bashir, S., Mustafa, A., Abbasi, G. H., Xue, B., Ali, U. (2019): Ameliorative effects of biochar on rapeseed (Brassica napus L.) growth and heavy metal immobilization in soil irrigated with untreated wastewater. - Journal of Plant Growth and Regulations 15: 1-16.

[23] Libutti, S. K., Tamarkin, L., Nilubol, N. (2018): Targeting the invincible barrier for drug delivery in solid cancers: interstitial fluid pressure. - Oncotarget 9: 35723-35725.

[24] Manzoor, M., Gul, S., Khan, H. (2019): Influence of biochars on yield and nitrogen and phosphorus use efficiency of Pisum sativum under groundwater and wastewater irrigation in arid climate. - Communication in soil sciences and Plant Analysis 50: 1563-1579.

[25] Mensah, A. K., Frimpong, K. A. (2018): Biochar and/or compost applications improve soil properties, growth, and yield of maize grown in acidic rainforest and coastal savannah soils in Ghana. - International Journal of Agronomy 2018: 1-8.

[26] Murtaza, G., Ghafoor, A., Qadir, M., Owens, G., Aziz, M. A., Zia, M. H. (2010): Disposal and use of sewage on agricultural lands in Pakistan: a review. - Pedosphere 20: 23-34.

[27] Nelissen, V., Saha, B. K., Ruysschaert, G., Boeckx, P. (2014): Effect of different biochar and fertilizer types on $\mathrm{N}_{2} \mathrm{O}$ and $\mathrm{NO}$ emissions. - Soil Biology and Biochemistry 70: 244255 . 
[28] Nelson, N. O., Janke, R. R. (2007): Phosphorus sources and management in organic production systems - Hortechnology 17: 442-454.

[29] Nzediegwu, C., Prasher, S., Elsayed, E., Dhiman, J., Mawof, A., Patel, R. (2019): Effect of biochar on heavy metal accumulation in potatoes from wastewater irrigation. - Journal of Environmental Management 232: 153-164.

[30] Olmo,M., Alburquerque, J. A., Barrón, V., Del Campillo, M. C., Gallardo, A., Fuentes, M., Villar, R. (2014): Wheat growth and yield responses to biochar addition under Mediterranean climate conditions. - Biology and Fertility of Soil 50: 1177-1187.

[31] Ouyang, L., Wang, F., Tang, J., Yu, L., Zhang, R. (2013): Effects of biochar amendment on soil aggregates and hydraulic properties. - Journal of Soil Sciences and Plant Nutrition 13: 991-1002.

[32] Rawat, J., Saxena, J., Sanwal, P. (2019): Biochar: A Sustainable Approach for Improving Plant Growth and Soil Properties. - In: Rawat, J. et al. (eds.) Biochar - An Imperative Amendment for Soil and the Environment. IntechOpen, London.

[33] Reeve, J. R., Hoagland, L. A., Villalba, J. J., Carr, P. M., Atucha, A., Cambardella, C., Davis, D. R., Delate, K. (2016): Organic Farming, Soil Health, and Food Quality. Advances in Agronomy 137: 319-367.

[34] Sims, G. K., Ellsworth, T. R., Mulvaney, R. L. (1995): Microscale determination of inorganic nitrogen in water and soil extracts. - Communication in Soil Sciences and Plant Analysis 26: 303-316.

[35] Singh., Mavi, M., Singh, G., Singh, B. P., Singh., Sekhon, B., Choudhary, O. P., Sagi, S., Berry, R. (2018): Interactive effects of rice-residue biochar and $\mathrm{N}$-fertilizer on soil functions and crop biomass in contrasting soils. - Journal of Soil Sciences and Plant Nutrition 18: 41-59.

[36] Tamura, K., Dudley, J., Nei, M., Kumar. S. (2007): MEGA4: molecular evolutionary genetics analysis (MEGA) software version 4.0. - Molecular Biology and Evolution 24: 1596-1599.

[37] Thompson, J. D., Gibson, T. J., Plewniak, F., Jeanmougin, F., Higgins, D. G. (1997): The CLUSTAL_X windows interface: flexible strategies for multiple sequence alignment aided by quality analysis tools. - Nucleic Acids Research and Special Publication 24: 4876-4882.

[38] Tóthmérész, B. (1995): Comparison of different methods for diversity ordering. - Journal of Vegetation Science 6: 283-290.

[39] Unkovich, M., Baldock, J., Forbes. M. (2010): Variability in harvest index of grain crops and potential significance for carbon accounting: examples from Australian agriculture. Advances in Agronomy 105: 173-219.

[40] Yadav, M. R., Kumar, R., Parihar, C. M., Yadav, R. K., Jat, S. L., Ram, H., Meena, R. K., Singh, M., Verma, A. P., Kumar, U., Ghosh, A. (2018): Strategies for improving nitrogen use efficiency: a review. - Agricultural Reviews 38: 29-4. 


\section{APPENDIX}

Table A1. Treatments with their replicates, mean and skewness values of harvest index (Data to Fig. 3 in the article)

\begin{tabular}{|c|c|c|c|c|c|c|c|c|}
\hline \multirow{3}{*}{ Treatments } & \multicolumn{4}{|c|}{ GW } & \multicolumn{4}{|c|}{ WW } \\
\hline & 2016 & & 2017 & & 2016 & & 2017 & \\
\hline & HI & R+MSL & HI & R+MSL & HI & R+MSL & HI & R+MSL \\
\hline \multirow{3}{*}{ Control } & 42.05 & & 36.80 & & 29.72 & & 9.66 & \\
\hline & 47.51 & 42.23 & 27.42 & 36.53 & 31.21 & 28.95 & 68.00 & 36.53 \\
\hline & 37.13 & SKEW $=0.06$ & 17.99 & SKEW $=-0.003$ & 25.91 & SKEW=-0.475 & 31.94 & SKEW $=0.279$ \\
\hline \multirow{3}{*}{ BM5 } & 31.45 & & 50.88 & & 21.39 & & 18.03 & \\
\hline & 41.68 & 32.17 & 35.41 & 24.30 & 26.04 & 25.83 & 27.48 & 24.30 \\
\hline & 23.37 & SKEW $=0.14$ & 32.41 & SKEW=0.635 & 30.05 & SKEW=-0.091 & 27.39 & SKEW $=-0.706$ \\
\hline \multirow{3}{*}{ BM10 } & 56.76 & & 50.35 & & 36.70 & & 28.57 & \\
\hline & 53.13 & 52.29 & 42.86 & 29.68 & 41.46 & 35.06 & 37.07 & 29.68 \\
\hline & 46.97 & SKEW $=-0.30$ & 48.31 & SKEW=-0.492 & 27.03 & SKEW=-0.388 & 23.40 & SKEW $=0.287$ \\
\hline \multirow{3}{*}{ BM15 } & 44.68 & & 29.62 & & 13.16 & & 28.00 & \\
\hline & 46.78 & 43.10 & 39.14 & 29.55 & 26.55 & 19.98 & 22.44 & 29.55 \\
\hline & 37.85 & SKEW $=-0.55$ & 30.42 & SKEW=0.688 & 20.23 & SKEW=-0.068 & 38.21 & SKEW $=0.342$ \\
\hline \multirow{3}{*}{ BW5 } & 43.32 & & 39.46 & & 22.80 & & 24.91 & \\
\hline & 49.30 & 44.28 & 78.48 & 30.64 & 28.19 & 23.96 & 31.52 & 30.64 \\
\hline & 40.22 & SKEW $=0.36$ & 34.14 & SKEW=0.668 & 20.90 & SKEW $=0.510$ & 35.48 & SKEW $=-0.295$ \\
\hline \multirow{3}{*}{ BW10 } & 41.86 & & 14.34 & & 31.83 & & 12.73 & \\
\hline & 44.44 & 44.37 & 35.67 & 21.64 & 36.96 & 29.62 & 20.13 & 21.64 \\
\hline & 46.79 & SKEW $=-0.06$ & 52.04 & SKEW=-0.159 & 20.06 & SKEW=-0.438 & 32.08 & SKEW $=0.278$ \\
\hline \multirow{3}{*}{ BW15 } & 44.56 & & 46.09 & & 32.76 & & 25.83 & \\
\hline & 40.97 & 35.98 & 66.35 & 26.05 & 18.53 & 21.83 & 18.99 & 26.05 \\
\hline & 22.41 & SKEW $=-0.64$ & 50.99 & SKEW=0.539 & 14.20 & SKEW=0.552 & 33.33 & SKEW=0.055 \\
\hline \multirow{3}{*}{ BW.65 (5) } & 38.85 & & 26.80 & & 33.42 & & 25.93 & \\
\hline & 50.36 & 32.17 & 46.23 & 26.40 & 28.52 & 27.26 & 22.22 & 26.40 \\
\hline & 45.65 & SKEW $=-0.22$ & 52.41 & SKEW $=-0.541$ & 19.83 & SKEW=-0.326 & 31.06 & SKEW $=0.195$ \\
\hline \multirow{3}{*}{ BW.65(10) } & 57.63 & & 50.17 & & 24.67 & & 28.18 & \\
\hline & 52.49 & 50.47 & 29.35 & 27.77 & 10.12 & 20.16 & 25.00 & 27.77 \\
\hline & 41.29 & SKEW $=-0.42$ & 71.69 & SKEW $=0.020$ & 25.69 & SKEW=-0.696 & 30.13 & SKEW $=-0.282$ \\
\hline \multirow{3}{*}{ BW.65(15) } & 50.82 & & 49.29 & & 23.42 & & 29.25 & \\
\hline & 16.82 & 39.43 & 32.22 & 34.30 & 32.90 & 30.66 & 30.49 & 34.30 \\
\hline & 50.66 & SKEW $=-0.71$ & 41.14 & SKEW $=-0.055$ & 35.67 & SKEW=-0.562 & 43.18 & SKEW $=0.686$ \\
\hline
\end{tabular}

Table A2. Treatments with their replicates, mean and skewness values of available phosphorus and nitrogen in soil (Data to Fig. 4 in the article)

\begin{tabular}{|c|c|c|c|c|c|c|c|c|}
\hline \multirow{3}{*}{ Treatments } & \multicolumn{4}{|c|}{ Phosphorus } & \multicolumn{4}{|c|}{ Nitrogen } \\
\hline & \multicolumn{2}{|c|}{ GW } & \multicolumn{2}{|c|}{ WW } & \multicolumn{2}{|r|}{ GW } & \multicolumn{2}{|c|}{ WW } \\
\hline & Phosphorus & R+MSL & Phosphorus & R+MSL & Nitrogen & R+MSL & Nitrogen & R+MSL \\
\hline \multirow{3}{*}{ Control } & 4.31 & & 4.31 & & 1.02 & & 4.51 & \\
\hline & 2.91 & 3.87 & 8.62 & 6.89 & 2.33 & 1.92 & 3.95 & 4.08 \\
\hline & 4.39 & SKEW $=-0.7$ & 7.75 & SKEW $=-0.591$ & 2.41 & SKEW=-0.69 & 3.78 & SKEW $=0.54$ \\
\hline \multirow{3}{*}{ BM5 } & 6.18 & & 6.18 & & 2.59 & & 5.18 & \\
\hline & 4.65 & 5.94 & 8.07 & 7.70 & 2.68 & 2.19 & 4.94 & 4.83 \\
\hline & 6.98 & SKEW $=-0.365$ & 8.86 & SKEW $=-0.453$ & 1.31 & SKEW=-0.697 & 4.36 & SKEW $=-0.45$ \\
\hline \multirow{3}{*}{ BM10 } & 7.56 & & 7.71 & & 3.10 & & 3.60 & \\
\hline & 4.08 & 7.22 & 5.99 & 7.47 & 0.77 & 1.79 & 3.33 & 3.82 \\
\hline & 10.00 & SKEW=-0.209 & 8.71 & SKEW $=-0.314$ & 1.49 & SKEW $=0.42$ & 4.51 & SKEW $=0.56$ \\
\hline
\end{tabular}


Manzoor et al.: Harvest index of pea plant and soil properties as influenced by a two-year amendment of biocarbons under municipal wastewater irrigation in arid climate - 2129 -

\begin{tabular}{|c|c|c|c|c|c|c|c|c|}
\hline \multirow{3}{*}{ BM15 } & 9.00 & & 7.00 & & 2.75 & & 3.42 & \\
\hline & 8.92 & 8.74 & 9.88 & 8.12 & 2.62 & 2.14 & 2.65 & 2.74 \\
\hline & 8.29 & SKEW=-0.675 & 7.46 & SKEW $=0.636$ & 1.06 & SKEW $=-0.693$ & 2.16 & SKEW $=0.26$ \\
\hline \multirow{3}{*}{ BW5 } & 5.28 & & 7.64 & & 4.41 & & 4.72 & \\
\hline & 5.75 & 4.91 & 7.77 & 7.45 & 1.81 & 2.62 & 2.75 & 3.97 \\
\hline & 3.71 & SKEW $=-0.558$ & 6.95 & SKEW $=-0.636$ & 1.63 & SKEW=0.696 & 4.43 & SKEW $=-0.65$ \\
\hline \multirow{3}{*}{ BW10 } & 4.25 & & 7.14 & & 2.22 & & 4.36 & \\
\hline & 5.17 & 4.22 & 7.18 & 6.99 & 3.07 & 2.3 & 4.19 & 4.22 \\
\hline & 3.24 & SKEW=-0.061 & 6.64 & SKEW=-0.691 & 1.61 & SKEW=0.199 & 4.11 & SKEW $=0.45$ \\
\hline \multirow{3}{*}{ BW15 } & 4.21 & & 6.60 & & 3.42 & & 4.67 & \\
\hline & 5.35 & 4.92 & 9.44 & 8.06 & 3.01 & 2.99 & 4.74 & 3.22 \\
\hline & 5.19 & SKEW $=-0.652$ & 8.12 & SKEW $=-0.087$ & 2.55 & SKEW $=-0.055$ & 0.26 & SKEW $=-0.71$ \\
\hline \multirow{3}{*}{ BW.65 (5) } & 3.24 & & 7.40 & & 2.15 & & 4.18 & \\
\hline & 3.05 & 3.45 & 5.90 & 6.71 & 3.26 & 2.08 & 3.46 & 4.13 \\
\hline & 4.06 & SKEW=0.606 & 6.83 & SKEW $=-0.280$ & 0.83 & SKEW $=-0.107$ & 4.74 & SKEW =-0.16 \\
\hline \multirow{3}{*}{ BW.65(10) } & 4.44 & & 7.42 & & 3.75 & & 4.52 & \\
\hline & 4.06 & 5.22 & 7.80 & 6.76 & 2.56 & 2.63 & 4.25 & 4.03 \\
\hline & 7.15 & SKEW $=0.665$ & 5.07 & SKEW=-0.655 & 1.59 & SKEW $=0.123$ & 3.32 & SKEW $=-0.57$ \\
\hline \multirow{3}{*}{ BW.65(15) } & 2.59 & & 7.68 & & 1.22 & & 3.94 & \\
\hline & 4.79 & 6.22 & 7.45 & 8.12 & 4.01 & 2.30 & 3.36 & 3.55 \\
\hline & 11.28 & SKEW $=0.523$ & 9.23 & SKEW $=0.664$ & 1.68 & SKEW $=0.630$ & 3.36 & SKEW $=0.71$ \\
\hline
\end{tabular}

Table A3. Treatments with their replicates, mean and skewness values of $p H$ and electrical conductivity of soil (Data to Table 4 in the article)

\begin{tabular}{|c|c|c|c|c|c|c|c|c|}
\hline \multirow{3}{*}{ Treatments } & \multicolumn{4}{|c|}{ EC } & \multicolumn{4}{|c|}{ pH } \\
\hline & \multicolumn{2}{|r|}{ GW } & \multirow{2}{*}{$\begin{array}{c}\text { WW } \\
\text { EC }\end{array}$} & \multirow[b]{2}{*}{ R+MSL } & \multirow{2}{*}{$\begin{array}{c}\text { GW } \\
\text { pH }\end{array}$} & \multirow[b]{2}{*}{ R+MSL } & \multirow{2}{*}{$\frac{\text { WW }}{\text { pH }}$} & \multirow[b]{2}{*}{ R+MSL } \\
\hline & EC & $\mathbf{R}+\mathbf{M S L}$ & & & & & & \\
\hline \multirow{3}{*}{ Control } & 812 & & 384 & & 9 & & 8.8 & \\
\hline & 461 & 495.00 & 457 & 459 & 9.1 & 9.27 & 8.9 & 8.90 \\
\hline & 212 & SKEW $=0.20$ & 536 & SKEW=0.048 & 9.7 & SKEW $=0.65$ & 9 & SKEW $=0.00$ \\
\hline \multirow{3}{*}{ BM5 } & 551 & & 447 & & 9.9 & & 8.7 & \\
\hline & 333 & 411.33 & 601 & 652.00 & 9.5 & 9.63 & 9 & 8.76 \\
\hline & 350 & SKEW=0.69 & 908 & SKEW $=0.380$ & 9.5 & SKEW=0.71 & 8.6 & SKEW $=0.53$ \\
\hline \multirow{3}{*}{ BM10 } & 719 & & 322 & & 9.4 & & 8.9 & \\
\hline & 506 & 551.00 & 351 & 552.33 & 9.5 & 9.50 & 8.9 & 8.83 \\
\hline & 428 & SKEW $=0.50$ & 984 & SKEW=0.702 & 9.6 & SKEW $=0.00$ & 8.7 & SKEW $=-0.71$ \\
\hline \multirow{3}{*}{ BM15 } & 391 & & 438 & & 9.7 & & 8.9 & \\
\hline & 265 & 312.33 & 574 & 478.33 & 9.8 & 9.67 & 9 & 8.93 \\
\hline & 281 & SKEW=0.66 & 423 & SKEW=0.681 & 9.5 & SKEW=-0.38 & 8.9 & SKEW $=0.71$ \\
\hline \multirow{3}{*}{ BW5 } & 310 & & 605 & & 9.7 & & 8.3 & \\
\hline & 212 & 284.67 & 488 & 541.67 & 9.3 & 9.50 & 8.8 & 8.67 \\
\hline & 332 & SKEW=-0.61 & 532 & SKEW=0.292 & 9.5 & SKEW=0.00 & 8.9 & SKEW $=-0.63$ \\
\hline \multirow{3}{*}{ BW10 } & 267 & & 300 & & 9.7 & & 8.9 & \\
\hline & 722 & 420.67 & 521 & 456.67 & 9.5 & 9.23 & 8.9 & 8.93 \\
\hline & 273 & SKEW=0.71 & 549 & SKEW $=-0.674$ & 8.5 & SKEW=-0.63 & 9 & SKEW $=0.71$ \\
\hline \multirow{3}{*}{ BW15 } & 475 & & 624 & & 9.8 & & 8.8 & \\
\hline & 299 & 392.00 & 693 & 593.00 & 9 & 9.47 & 8.8 & 8.83 \\
\hline & 402 & SKEW=-0.21 & 462 & SKEW $=-0.447$ & 9.6 & SKEW=-0.53 & 8.9 & SKEW $=0.71$ \\
\hline BW.65 (5) & 575 & & 490 & & 9.7 & & 8.8 & \\
\hline
\end{tabular}




\begin{tabular}{c|c|c|c|c|c|c|c|c}
\hline & 300 & 397.67 & 508 & 512.67 & 9.5 & 9.37 & 9 & 8.87 \\
\cline { 2 - 9 } & 318 & SKEW=0.70 & 540 & SKEW=0.327 & 8.9 & SKEW=-0.53 & 8.8 & SKEW=0.71 \\
\hline \multirow{3}{*}{ BW.65 (10) } & 583 & & 603 & & 9.3 & & 9 & \\
\cline { 2 - 9 } & 277 & 391.00 & 853 & 680.00 & 9.6 & 9.30 & 9 & 8.97 \\
\cline { 2 - 10 } & 313 & SKEW=-0.67 & 584 & SKEW=0.694 & 9 & SKEW=0.00 & 8.9 & SKEW=-0.71 \\
\hline \multirow{3}{*}{ BW.65 (15) } & 739 & & 538 & & 9 & & 8.8 & \\
\cline { 2 - 10 } & 408 & 540.00 & 476 & 571.00 & 9.5 & 9.43 & 8.9 & 8.87 \\
\cline { 2 - 9 } & 473 & SKEW $=0.60$ & 699 & SKEW $=0.483$ & 9.8 & SKEW=-0.29 & 8.9 & SKEW=-0.71 \\
\hline
\end{tabular}

Table A4. Treatments with their replicates, mean and skewness values of organic matter of soil (Data to Table 4 in the article)

\begin{tabular}{|c|c|c|c|c|}
\hline \multirow{2}{*}{ Treatments } & \multicolumn{2}{|c|}{ GW } & \multicolumn{2}{|c|}{ WW } \\
\hline & OM & R+MSL & OM & R+MSL \\
\hline \multirow{3}{*}{ Control } & 14.22 & & 27.30 & \\
\hline & 10.12 & 14.21 & 28.10 & 26.25 \\
\hline & 18.28 & SKEW $=-0.01$ & 23.36 & SKEW $=-0.63$ \\
\hline \multirow{3}{*}{ BM5 } & 18.81 & & 25.35 & \\
\hline & 13.71 & 16.92 & 25.36 & 25.68 \\
\hline & 18.25 & SKEW $=-0.67$ & 26.33 & SKEW $=0.71$ \\
\hline \multirow{3}{*}{ BM10 } & 17.08 & & 19.79 & \\
\hline & 12.14 & 16.33 & 19.42 & 21.60 \\
\hline & 19.77 & SKEW $=-0.34$ & 25.60 & SKEW $=0.70$ \\
\hline \multirow{3}{*}{ BM15 } & 14.53 & & 21.46 & \\
\hline & 12.15 & 29.22 & 29.82 & 25.13 \\
\hline & 60.98 & SKEW $=0.70$ & 24.11 & SKEW $=0.41$ \\
\hline \multirow{3}{*}{ BW5 } & 15.76 & & 43.28 & \\
\hline & 26.40 & 21.32 & 33.33 & 38.47 \\
\hline & 21.81 & SKEW=-0.17 & 38.81 & SKEW $=-0.12$ \\
\hline \multirow{3}{*}{ BW10 } & 19.27 & & 39.09 & \\
\hline & 27.92 & 22.83 & 41.88 & 39.34671 \\
\hline & 21.31 & SKEW $=0.55$ & 37.08 & SKEW $=0.20$ \\
\hline \multirow{3}{*}{ BW15 } & 24.38 & & 54.09 & \\
\hline & 35.81 & 29.55 & 62.34 & 51.74 \\
\hline & 28.46 & SKEW $=0.33$ & 38.80 & SKEW $=-0.35$ \\
\hline \multirow{3}{*}{ BW.65 (5) } & 20.39 & & 33.81 & \\
\hline & 14.24 & 18.99 & 25.07 & 28.73 \\
\hline & 22.34 & SKEW $=-0.54$ & 27.30 & SKEW $=0.52$ \\
\hline \multirow{3}{*}{ BW.65 (10) } & 29.93 & & 49.56 & \\
\hline & 20.86 & 20.49 & 39.43 & 39.22 \\
\hline & 10.68 & SKEW=-0.07 & 28.66 & SKEW $=-0.04$ \\
\hline \multirow{3}{*}{ BW.65 (15) } & 25.35 & & 45.48 & \\
\hline & 29.95 & 27.56 & 29.95 & 34.99 \\
\hline & 27.38 & SKEW $=0.14$ & 29.55 & SKEW $=0.71$ \\
\hline
\end{tabular}

Table A5. Treatments with their replicates, mean and skewness values of soil aggregates under groundwater irrigation in soil (Data to Fig. 5 in the article)

\begin{tabular}{|c|c|c|c|c|c|c|c|c|}
\hline \multirow{2}{*}{ Treatments } & \multicolumn{8}{|c|}{ GW } \\
\hline & $2 \mathrm{~mm}$ & R+MSL & $1.5 \mathrm{~mm}$ & $\mathbf{R}+\mathbf{M S L}$ & $1 \mathrm{~mm}$ & R+MSL & $0.5 \mathrm{~mm}$ & R+MSL \\
\hline \multirow{3}{*}{ Control } & 2.736009 & & 4.888195 & & 2.429318 & & 50.65841 & \\
\hline & 7.285806 & 7.43 & 5.63797 & 5.95 & 3.543336 & 2.15 & 39.63722 & 45.12 \\
\hline & 12.28112 & SKEW $=0.06$ & 7.310892 & SKEW $=0.43$ & 0.478925 & SKEW $=-0.32$ & 45.05026 & SKEW $=0.02$ \\
\hline BM5 & 9.985176 & & 6.28561 & & 1.973618 & & 45.9584 & \\
\hline
\end{tabular}


Manzoor et al.: Harvest index of pea plant and soil properties as influenced by a two-year amendment of biocarbons under municipal wastewater irrigation in arid climate - 2131 -

\begin{tabular}{|c|c|c|c|c|c|c|c|c|}
\hline & 9.748876 & 8.79 & 5.502547 & 5.78 & 3.52692 & 3.47 & 46.37159 & 49.38 \\
\hline & 6.637308 & SKEW $=-0.69$ & 5.543312 & SKEW $=0.70$ & 4.91096 & SKEW $=-0.07$ & 55.79639 & SKEW $=0.70$ \\
\hline \multirow{3}{*}{ BM10 } & 12.45582 & & 4.973254 & & 0.867607 & & 36.45588 & \\
\hline & 3.919806 & 8.42 & 5.015299 & 6.03 & 3.068777 & 2.34 & 50.85363 & 43.09 \\
\hline & 8.870346 & SKEW=-0.19 & 8.110636 & SKEW $=0.71$ & 3.080003 & SKEW $=-0.71$ & 41.96749 & SKEW $=0.28$ \\
\hline \multirow{3}{*}{ BM15 } & 5.742632 & & 5.102102 & & 1.627448 & & 39.38699 & \\
\hline & 3.240332 & 5.77 & 8.272209 & 6.59 & 4.493055 & 3.44 & 48.31318 & 45.30 \\
\hline & 8.324085 & SKEW=0.02 & 6.396105 & SKEW=0.22 & 4.198041 & SKEW $=-0.68$ & 48.20249 & SKEW $=-0.70$ \\
\hline \multirow{3}{*}{ BW5 } & 4.60829 & & 5.81425 & & 1.08485 & & 49.24993 & \\
\hline & 16.7014 & 8.33 & 6.419233 & 5.75 & 8.969978 & 4.25 & 26.98852 & 41.26 \\
\hline & 3.666492 & SKEW=0.69 & 5.02482 & SKEW $=-0.16$ & 2.695575 & SKEW=0.59 & 47.55044 & SKEW $=-0.69$ \\
\hline \multirow{3}{*}{ BW10 } & 5.043806 & & 3.125664 & & 0.886441 & & 43.67078 & \\
\hline & 4.386047 & 3.82 & 3.865082 & 3.53 & 0.651206 & 1.17 & 51.15278 & 47.60 \\
\hline & 2.025192 & SKEW $=-0.57$ & 3.589129 & SKEW $=-0.30$ & 1.981292 & SKEW=0.62 & 47.9755 & SKEW $=-0.18$ \\
\hline \multirow{3}{*}{ BW15 } & 4.750178 & & 2.172818 & & 0.906237 & & 43.12011 & \\
\hline & 12.93283 & 6.77 & 7.090777 & 4.52 & 4.675428 & 2.85 & 48.52959 & 48.98 \\
\hline & 2.633543 & SKEW=0.59 & 4.288641 & SKEW=0.17 & 2.975353 & SKEW $=-0.12$ & 55.29207 & SKEW=0.14 \\
\hline \multirow{3}{*}{ BW.65 (5) } & 7.340262 & & 3.271642 & & 2.293869 & & 47.86555 & \\
\hline & 3.840444 & 8.26 & 6.791311 & 5.19 & 3.438216 & 2.63 & 42.26027 & 46.13 \\
\hline & 13.60005 & SKEW $=0.33$ & 5.504442 & SKEW $=-0.32$ & 2.154307 & SKEW=0.68 & 48.24992 & SKEW $=-0.70$ \\
\hline \multirow{3}{*}{ BW.65(10) } & 7.444499 & & 6.498663 & & 1.561937 & & 35.22507 & \\
\hline & 5.253505 & 8.29 & 6.565133 & 6.13 & 2.188311 & 2.36 & 51.64258 & 46.77 \\
\hline & 12.17171 & $\mathrm{SKEW}=0.41$ & 5.338416 & SKEW $=-0.70$ & 3.329189 & SKEW=0.34 & 53.42874 & SKEW $=-0.68$ \\
\hline \multirow{3}{*}{ BW.65(15) } & 10.50179 & & 6.983791 & & 4.382236 & & 36.30166 & \\
\hline & 21.34858 & 15.02 & 2.463665 & 4.06 & 0.48168 & 4.29 & 41.37479 & 42.10 \\
\hline & 13.19686 & SKEW $=0.53$ & 2.722287 & SKEW $=0.70$ & 8.008052 & SKEW $=-0.04$ & 48.61392 & SKEW $=0.21$ \\
\hline
\end{tabular}

Figure A6. Treatments with their replicates, mean and skewness values of soil aggregates under wastewater irrigation in soil (Data to Fig. 5 in the article)

\begin{tabular}{|c|c|c|c|c|c|c|c|c|}
\hline \multirow{2}{*}{ Treatments } & \multicolumn{8}{|c|}{ Wastewater irrigation } \\
\hline & $2 \mathrm{~mm}$ & R+MSL & $1.5 \mathrm{~mm}$ & R+MSL & $1 \mathrm{~mm}$ & R+MSL & $0.5 \mathrm{~mm}$ & R+MSL \\
\hline \multirow{3}{*}{ Control } & 17.09 & & 19.05 & & 8.06 & & 35.59 & \\
\hline & 20.74 & 21.00 & 19.07 & 18.16 & 9.63 & 8.47 & 36.74 & 35.96 \\
\hline & 25.16 & $\mathrm{SKEW}=0.12$ & 16.35 & SKEW=-0.71 & 7.73 & SKEW $=0.62$ & 35.56 & SKEW $=0.71$ \\
\hline \multirow{3}{*}{ BM5 } & 22.52 & & 19.98 & & 6.18 & & 33.21 & \\
\hline & 31.92 & 26.61 & 16.54 & 18.74 & 6.88 & 6.33 & 23.76 & 29.82 \\
\hline & 25.38 & SKEW $=0.44$ & 19.69 & SKEW=-0.69 & 5.94 & SKEW $=0.52$ & 32.48 & SKEW $=-0.69$ \\
\hline \multirow{3}{*}{ BM10 } & 15.58 & & 18.24 & & 8.00 & & 40.12 & \\
\hline & 15.88 & 16.99 & 15.94 & 16.11 & 10.28 & 9.15 & 44.60 & 40.98 \\
\hline & 19.52 & SKEW=0.69 & 14.14 & SKEW=0.15 & 9.18 & SKEW $=-0.04$ & 38.22 & SKEW $=0.45$ \\
\hline \multirow{3}{*}{ BM15 } & 8.47 & & 20.59 & & 9.07 & & 9.41 & \\
\hline & 19.64 & 15.34 & 16.98 & 18.80 & 6.80 & 7.93 & 38.12 & 26.61 \\
\hline & 17.90 & SKEW $=-0.64$ & 18.84 & SKEW=-0.04 & 7.92 & SKEW $=0.01$ & 32.30 & SKEW $=-0.59$ \\
\hline \multirow{3}{*}{ BW5 } & 30.13 & & 22.73 & & 7.16 & & 22.47 & \\
\hline & 7.50 & 15.20 & 13.56 & 17.93 & 5.76 & 8.20 & 48.70 & 35.69 \\
\hline & 7.98 & SKEW $=0.71$ & 17.50 & SKEW=0.17 & 11.68 & SKEW $=0.55$ & 35.90 & SKEW $=-0.03$ \\
\hline \multirow{3}{*}{ BW10 } & 30.28 & & 18.51 & & 5.43 & & 30.14 & \\
\hline & 10.18 & 19.15 & 11.62 & 15.37 & 6.88 & 6.82 & 44.76 & 38.35 \\
\hline & 16.98 & SKEW $=0.37$ & 15.98 & SKEW=-0.31 & 8.16 & SKEW $=-0.08$ & 40.16 & SKEW $=-0.42$ \\
\hline \multirow{3}{*}{ BW15 } & 27.27 & & 22.11 & & 9.33 & & 26.47 & \\
\hline & 17.98 & 20.11 & 17.38 & 18.83 & 8.98 & 9.78 & 34.92 & 32.52 \\
\hline & 15.08 & SKEW $=0.55$ & 17.00 & SKEW=0.69 & 11.02 & SKEW $=0.63$ & 36.18 & SKEW $=-0.66$ \\
\hline \multirow{2}{*}{ BW.65 (5) } & 14.50 & & 18.92 & & 6.41 & & 6.41 & \\
\hline & 18.48 & 18.37 & 14.82 & 17.25 & 8.26 & 7.52 & 42.78 & 26.04 \\
\hline
\end{tabular}


Manzoor et al.: Harvest index of pea plant and soil properties as influenced by a two-year amendment of biocarbons under municipal wastewater irrigation in arid climate

$$
\text { - } 2132 \text { - }
$$

\begin{tabular}{c|c|c|c|c|c|c|c|c}
\hline & 22.12 & SKEW=-0.05 & 18.02 & SKEW=-0.57 & 7.90 & SKEW=-0.60 & 28.92 & SKEW=-0.28 \\
\hline \multirow{4}{*}{ BW.65(10) } & 25.65 & & 21.74 & & 7.71 & & 27.27 & \\
\cline { 2 - 9 } & 6.50 & 16.42 & 14.96 & 16.56 & 8.96 & 8.33 & 36.64 & 30.50 \\
\cline { 2 - 9 } & 17.12 & SKEW=-0.13 & 12.98 & SKEW=0.56 & 8.32 & SKEW=0.03 & 27.60 & SKEW=0.70 \\
\hline \multirow{3}{*}{ BW.65(15) } & 25.02 & & 10.23 & & 18.41 & & 29.38 & \\
\cline { 2 - 9 } & 14.04 & 20.88 & 14.72 & 15.38 & 10.50 & 11.60 & 45.26 & 34.90 \\
\cline { 2 - 9 } & 23.58 & SKEW=-0.66 & 21.20 & SKEW=0.22 & 5.90 & SKEW $=0.31$ & 30.06 & SKEW=0.70 \\
\hline
\end{tabular}

